\title{
PCFB Repowering Project 80 MW Plant Description
}

\author{
Topical Report
}

May 1994

Work Performed Under Contract No.: DE-FC21-91MC27364

For

U.S. Department of Energy

Office of Fossil Energy

Morgantown Energy Technology Center

Morgantown, West Virginia

By

Midwest Power Systems, Inc.

Des Moines, lowa 


\section{DISCLAIMER}

This report was prepared as an account of work sponsored by an agency of the United States Government. Neither the United States Government nor any agency thereof, nor any of their employees, makes any warranty, express or implied, or assumes any legal liability or responsibility for the accuracy, completeness, or usefulness of any information, apparatus, product, or process disclosed, or represents that its use would not infringe privalely owned rights. Reference herein to any specific commercial product, process, or service by trade name, trademark, manufacturer, or otherwise does not necessarily constitute or imply its endorsement, recommendation, or favoring by the United States Government or any agency thereof. The views and opinions of authors expressed herein do not necessarily state or reflect those of the United States Government or any agency thereof.

This report has been reproduced directly from the best available copy.

Available to DOE and DOE contractors from the Office of Scientific and Technical Information, 175 Oak Ridge Turnpike, Oak Ridge, TN 37831; prices available at (615) 576-8401.

Available to the public from the National Technical Information Service, U.S. Department of Commerce, 5285 Port Royal Road, Springfield, VA 22161; phone orders accepted at (703) 487-4650. 


\section{DISCLAIMER}

Portions of this document may be illegible in electronic image products. Images are produced from the best available original document. 


\title{
PCFB Repowering Project 80 MW Plant Description
}

\author{
Topical Report
}

Work Performed Under Contract No.: DE-FC21-91MC27364

\author{
For \\ U.S. Department of Energy \\ Office of Fossil Energy \\ Morgantown Energy Technology Center \\ P.O. Box 880 \\ Morgantown, West Virginia 26507-0880
}

By

Midwest Power Systems, Inc.

907 Walnut Street

Box 657

Des Moines, lowa 50303-0657

May 1994 


\section{Table of Contents}

1.0 Executive Summary $\ldots \ldots \ldots \ldots \ldots \ldots \ldots \ldots \ldots \ldots \ldots$

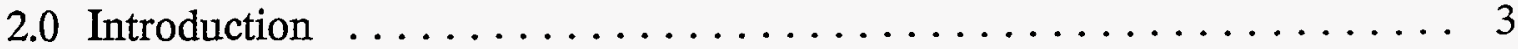

2.1 Pressurized Fluidized Bed Combustion $\ldots \ldots \ldots \ldots \ldots \ldots \ldots 4$

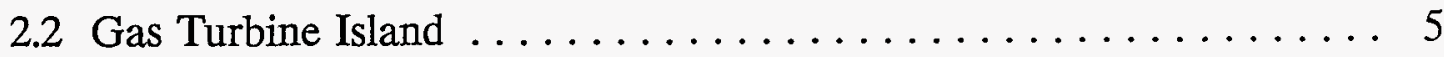

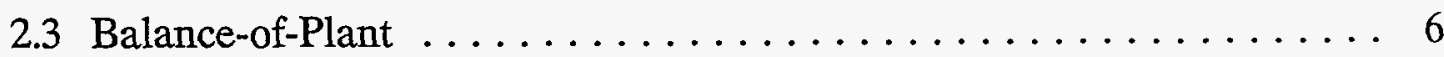

2.3.1 Coal Feed System $\ldots \ldots \ldots \ldots \ldots \ldots \ldots \ldots \ldots \ldots \ldots \ldots$

2.3.2 The Limestone Feed System ................. 8

2.3.3 PCFB Hot Loop ................... 9

2.3.4 Pressure Containment ....................... 14

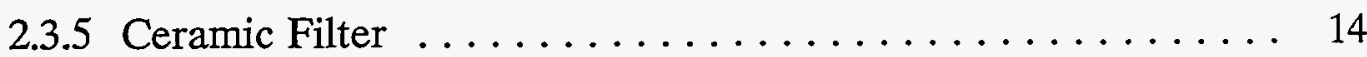

2.3.6 Ash Depressurization and Cooling System ............ 14

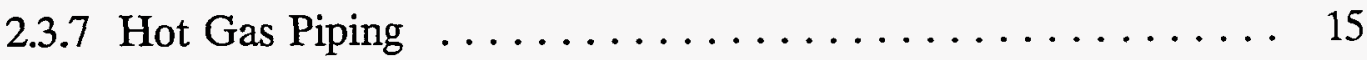

2.3.8 Heat Recovery Economizer $\ldots \ldots \ldots \ldots \ldots \ldots \ldots \ldots \ldots$

2.4 Integration with Existing Facilities $\ldots \ldots \ldots \ldots \ldots \ldots \ldots \ldots \ldots$

3.0 New Systems $\ldots \ldots \ldots \ldots \ldots \ldots \ldots \ldots \ldots \ldots \ldots \ldots \ldots \ldots . \ldots \ldots$

3.1 Pressurized Circulating Fluidized Bed Steam Generator . . . . . . 18

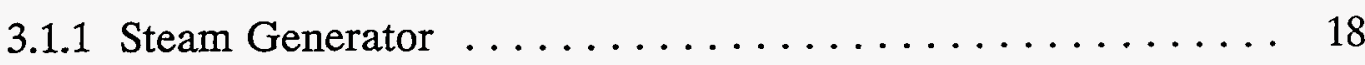

3.2.1 Gas Turbine Generator and Excitation ........... 28

3.3 Hot Side Gas Filtration ........................ 29

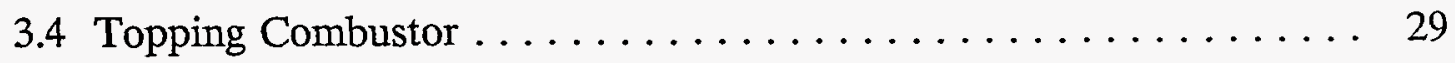

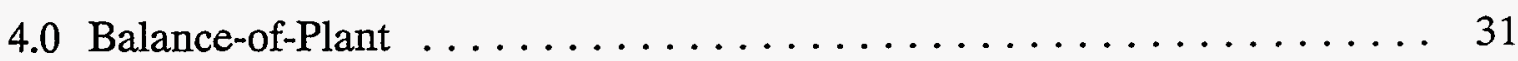

4.1 Limestone and Sand Handling . . . . . . . . . . . . . 31

4.1.1 Limestone and Sand Receiving $\ldots \ldots \ldots \ldots \ldots \ldots \ldots \ldots \ldots \ldots \ldots \ldots \ldots \ldots \ldots \ldots$

4.2 Coal Handling . . . . . . . . . . . . . 33

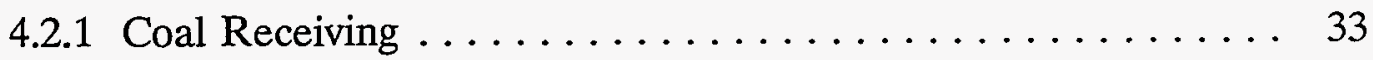

4.2.2 Coal Stockout and Reclaim ................ 33

4.2.3 Coal Bunker Fill and Crushing System $\ldots \ldots \ldots \ldots \ldots \ldots . \ldots \ldots$

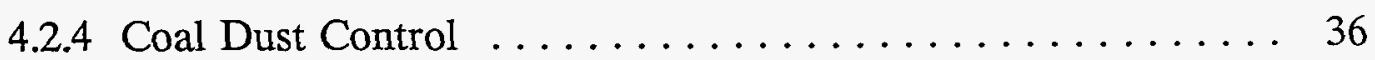

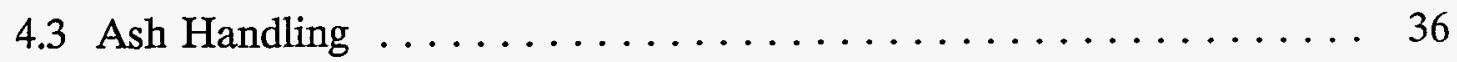

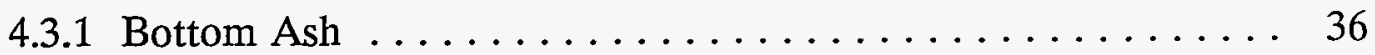




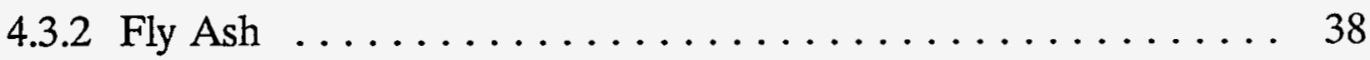

4.3.3 Combustion Waste Storage $\ldots \ldots \ldots \ldots \ldots \ldots \ldots \ldots \ldots$

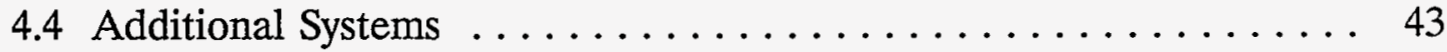

4.4 .1 Main Steam ....................... 43

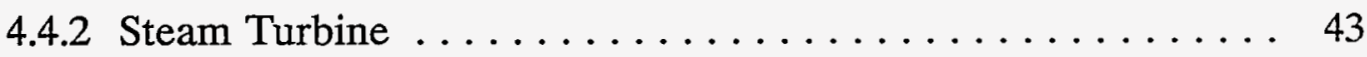

4.4 .3 Boiler Feed ....................... 46

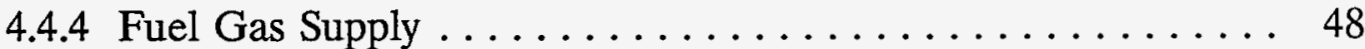

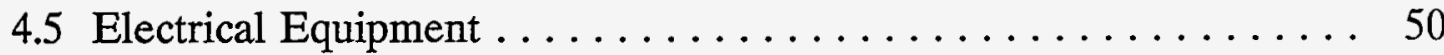

4.5.1 Generator Step-Up Transformer . ............. 50

4.5.2 Steam Turbine Generator and Excitation $\ldots \ldots \ldots \ldots \ldots 50$

4.6 System Control . . . . . . . . . . . . . . . . . 51

4.6.1 Distributed Control and Information ............. 51

4.6.2 Steam Turbine Controls and Instrumentation .......... 52

4.6.3 Automatic Generation Control ................ 53

4.6.4 Fuel Burning Control System $\ldots \ldots \ldots \ldots \ldots \ldots \ldots \ldots . \ldots \ldots$

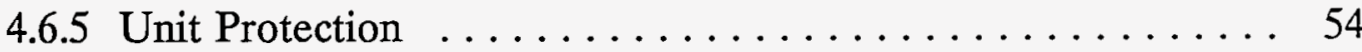

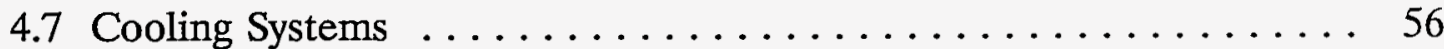

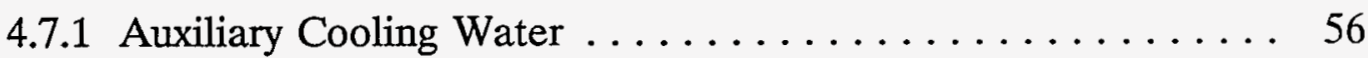

4.7.2 Closed Cycle Cooling Water ................ 56

4.7 .3 Condensate System . . . . . . . . . . . . . . . 58

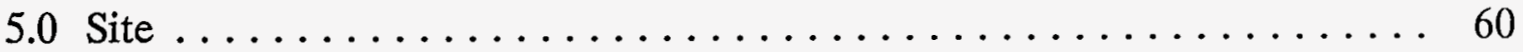

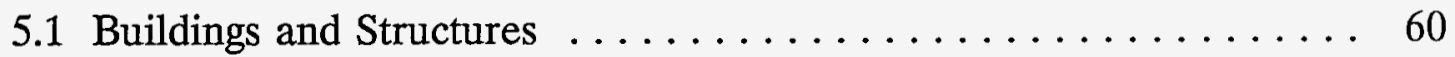

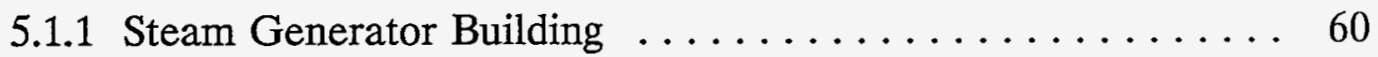

5.1.2 Turbine Generator Building/Auxiliary Bay .......... 63

5.1 .3 Gas Turbine Building $\ldots \ldots \ldots \ldots \ldots \ldots \ldots \ldots \ldots$

5.1.4 Administration/Plant Services Building (Existing Turbine Hall and

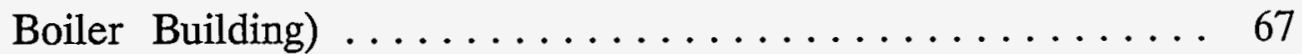

5.1.5 Coal Transfer Building (Existing Coal Crusher House) . . . . 68

5.1 .6 Gas Meter House . . . . . . . . . . . . . . . . 69

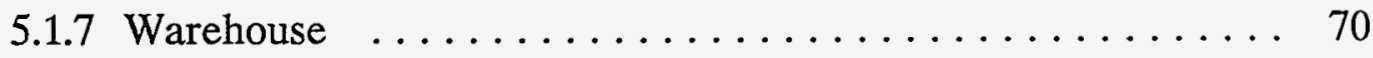

5.1.8 Circulating Water Chemical Feed Building $\ldots \ldots \ldots \ldots \quad 70$

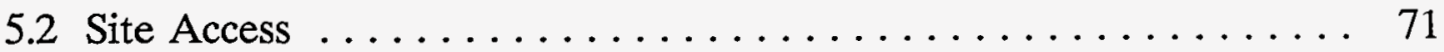

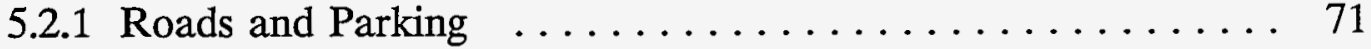

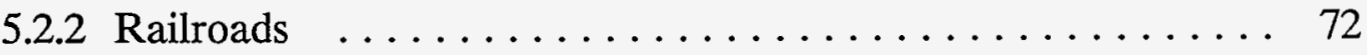




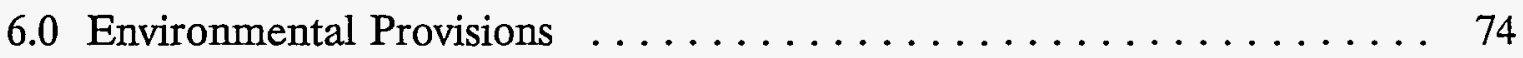

6.1 Combustion Gases Sampling and Analysis ............ 74

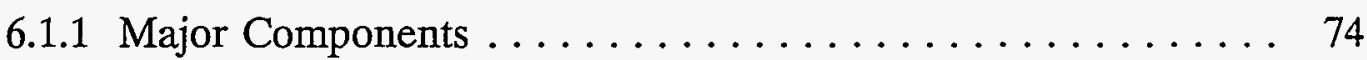

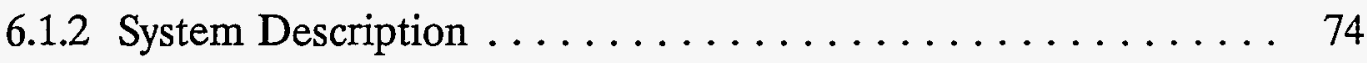

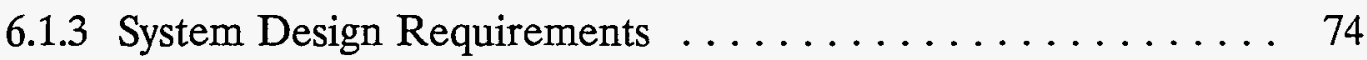

6.2 Calculation of Plant Emissions and Performance .......... 74

6.2.1 Carbon Conversion Efficiency $\ldots \ldots \ldots \ldots \ldots \ldots \ldots \ldots \ldots$

$6.2 .2 \mathrm{SO}_{2}$ Removal ...................... 76

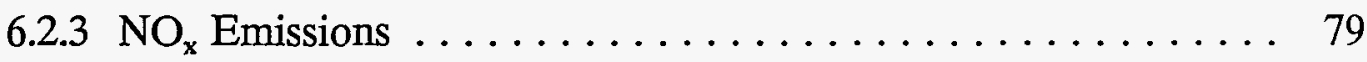

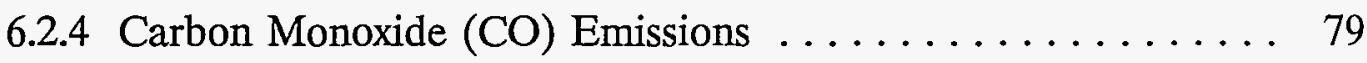

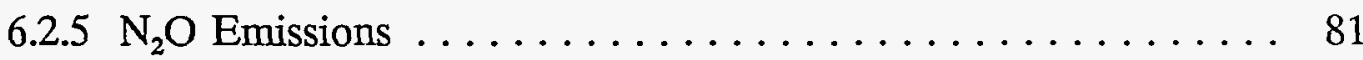




\section{List of Figures}

Figure 1: Pyroflow PCFB Process Flow Diagram .............. 4

Figure 2: Schematic of Fuel Feed System $\ldots \ldots \ldots \ldots \ldots \ldots \ldots \ldots$

Figure 3: Schematic of Limestone/Sand Feed System . . . . . . . . . . 10

Figure 4: Schematic of PCFB Hot Loop . . . . . . . . . . . . . 11

Figure 5: PCFB Connection to Existing Equipment at DMEC . . . . . . 16

Figure 6: Artist's Rendering of New Structure . . . . . . . . . . . 17

Figure 7: Boiler Feed and Steam Circuit Process Flow Diagram ........ 19

Figure 8: Combustion Air and Flue Gas Flow Process Flow Diagram . . . . 21

Figure 9: Steam Generator Fuel Supply Circuit

Figure 10: Steam Generator Sorbent Feed System . . . . . . . . . . 24

Figure 11: Steam Generator Sand Feed Circuit . . . . . . . . . . 26

Figure 12: Steam Generator Ash Removal Circuit . . . . . . . . . . 27

Figure 13: Limestone and Sand Handling System Flow Diagram . . . . . . 32

Figure 14: Coal Handling Process Flow Diagram $\ldots \ldots \ldots \ldots \ldots \ldots . \ldots . \ldots$

Figure 15: Ash Handling Process Flow Diagram . . . . . . . . . . . 37

Figure 16: Main Steam System Flow Diagram . . . . . . . . . . . . 44

Figure 17: Boiler Feed System Process Flow Diagram . . . . . . . . . . 47

Figure 18: Existing and Planned Plant Arrangements $\ldots \ldots \ldots \ldots \ldots 61$

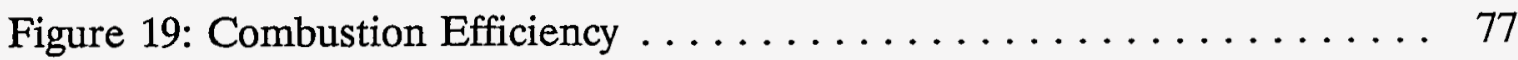

Figure 20: $\mathrm{SO}_{2}$ Removal Versus $\mathrm{Ca} / \mathrm{S}$ Molar Ratio $\ldots \ldots \ldots \ldots \ldots \ldots .78$

Figure 21: $\mathrm{NO}_{\mathrm{x}}$ Emission Versus Load $\ldots \ldots \ldots \ldots \ldots \ldots \ldots \ldots \ldots \ldots$

Figure 22: CO Emission Versus Load $\ldots \ldots \ldots \ldots \ldots \ldots \ldots \ldots \ldots$

\section{List of Tables}

Table 1: Predicted DMEC-1 Performance . . . . . . . . . . . . 75 


\section{List of Acronyms}

PCFB Pressurized Circulating Fluidized Bed

DMEC-1 Des Monies Energy Center

DOE Department of Energy

BN Burlington Northern

FRA Federal Railroad Administration

EPA Environmental Protection Agency

NSPS New Source Performance Standards

MW Megawatts

CFB Circulating Fluidized Bed

ACFB Atmospheric Circulating Fluidized Bed

$\mathrm{SO}_{2} \quad$ Sulfur dioxide

$\mathrm{NO}_{\mathbf{x}} \quad$ Nitrogen oxide

$\mathrm{Ca} \quad$ Calcium

$\mathrm{CaCO}_{3} \quad$ Calcium Carbonate

$\mathrm{CaSO}_{4} \quad$ Calcium Sulfate

$\mathrm{CO}_{2} \quad$ Carbon Dioxide

$\mathrm{O}_{2} \quad$ Oxygen

$\mathrm{S} \quad$ Sulfur

HRE Heat Recovery Economizer

DCIS Distributed Control and Information System

IDNR Iowa Department of Natural Resources

TCV Three Way temperature control valve

GEP Good Engineering Practice

DEH Digital Electrohydraulic

CRT Cathode Ray Tube

SOE Sequence-of-Events Recorder

CEMS Continuous Emissions Monitoring System

DAS Data Acquisition System 


\subsection{Executive Summary}

This report documents the design of a 80MW Pressurized Circulating Fluidized Bed (PCFB) boiler as it applies to the repowering of Unit 1 at the Des Moines Energy Center (DMEC-1). The objective of this effort is to demonstrate that PCFB combined-cycle technology, when operating at a commercial scale is a cost effective, reliable and environmentally superior technology when compared to traditional pulverized coal burning facilities. The Department of Energy is partially funding the effort under the Clean Coal Technology Program. The project is currently in the design phase, Phase I.

In August of 1991, Iowa Power and Dairyland Power Cooperative via the DMEC-1 Limited Partnership, entered into a Cooperative Agreement with the Department of Energy (DOE). Collectively, the two utilities, Pyropower Corporation, and Black \& Veatch initiated the preliminary design of the PCFB Repowering Project. As a result of a July 1992 merger between Iowa Power and Iowa Public Service, Midwest Power was formed and has fully assumed Iowa Power's role as General Partner of the DMEC-1 Limited Partnership. The PCFB Repowering project will demonstrate "First Generation" PCFB technology and will result in an existing steam turbine being repowered with steam from a PCFB boiler. Exhaust gases from the PCFB boiler will be expanded through a gas turbine to provide additional power output. The total power output for this demonstration project will be $87 \mathrm{MW}$ gross, $67 \mathrm{MW}$ from the steam turbine, and $20 \mathrm{MW}$ from the gas turbine.

There are three systems which are the new technologies being used in this demonstration project. They are the pressurized fluidized bed combustor, the gas turbine, and the hot side gas filtration. There is one new technology, the topping combustor, which is not used in this project due to unfavorable economics.

The remainder of the systems in the power plant are similar to those found in a conventional pulverized coal plant. Modifications will be made to the existing systems at the DMEC-1 site to accommodate the PCFB process. A sand and limestone handling system will be added. The coal handling system will be modified to accommodate the paste pumps. One of the feedwater heaters will be removed from the existing system; the condenser will be retubed. All other systems will be rebuilt, refurbished, and/or cleaned as necessary.

The site will also be modified to accommodate the new technology. There will be several new buildings added to the site as well. These include the following: 
- Steam Generator Building.

- Gas Turbine Building.

- Gas Meter House.

- Warehouse.

- Circulating Water Feed Building.

The existing turbine generator building, administrative building, and the coal transfer building will be modified or refurbished. Roads will be added to the site to provide access to the waste disposal area and the new buildings. Roads with sufficient traffic will be paved.

The Burlington Northern (BN) spur to the site will be upgraded to Federal Railroad Administration (FRA) Class 3 rail to incorporate larger shipments of coal by rail.

The PCFB plant is an efficient system which was designed maximize the combustion efficiency and to minimized the emissions of sulfur dioxide $\left(\mathrm{SO}_{2}\right)$ and nitrogen oxides $\left(\mathrm{NO}_{\mathrm{x}}\right)$. The plant will be equipped with a continuous emission monitoring system to monitor unit performance and to determine compliance with federal and state air quality regulations including those of the Environmental Protection Agency (EPA). 


\subsection{Introduction}

The PCFB Repowering Project will demonstrate "First Generation" PCFB technology and will result in an existing steam turbine at the DMEC-1 site being repowered with steam provided by a PCFB boiler. Exhaust gases from the PCFB boiler will be cleaned at $1,600^{\circ} \mathrm{F}$ and exhausted through a gas turbine which will provide over 20 percent of the resulting plant's net power output. The resulting improvement in the net plant heat rate of the DMEC-1 site will be about 15 percent better than that of the original steam plant, while emissions will be controlled within New Source Performance Standards.

Repowering of the existing steam turbine at DMEC-1 will result in about $87 \mathrm{MW}$ gross power generation. The plant will be designed to fire a range of coals including high sulfur bituminous coals from Illinois, Iowa, and low sulfur subbituminous western coal from the Powder River Basin in Wyoming. The PCFB will replace a retired pulverized coal fired boiler to repower an existing steam turbine. The steam conditions in the boiler are expected to be $506,200 \mathrm{lb} / \mathrm{h}$ at $1,300 \mathrm{psig}$ and $955^{\circ} \mathrm{F}$. Approximately $65 \mathrm{MW}$ will be produced from the steam turbine. The gas turbine will provide an additional $22 \mathrm{MW}$ of power.

The PCFB Repowering Project will combine the new technology of the AHLSTROM PYROFLOW ${ }^{\circledR}$ PCFB process with a conventional steam generation power plant. The unit will be designed and furnished by Pyropower Corporation, (located in San Diego, California and the US subsidiary of A. Ahlstrom Corporation of Helsinki, Finland). The project will be a commercial scale up from an existing PCFB test facility located in Karhula, Finland. Black \& Veatch (headquartered in Kansas City, Missouri) will be responsible for engineering the balance-of-plant.

This report will discuss the PCFB process and the major systems associated with an 87 MW PCFB plant at the Des Moines Energy Center location. It will present predicted plant performance data. The major systems that are associated with this demonstration plant which are not typically associated with a coal fired plant are the pressurized boiler, the gas turbine and compressor, and the hot side gas filtration system. There are many support systems to this process which may be similar to those found in a typical pulverized coal plant. This report will discuss how those systems work and how they may be modified from the existing systems at the DMEC-1 site. 


\subsection{Pressurized Fluidized Bed Combustion}

The PCFB process utilizes a combined cycle which employs a combination of a gas turbine and steam turbine to generate power. The pressurized combustion chamber is used to burn coal to produce steam for the steam turbine which produces 75 to 80 percent of the plant output. The hot flue gases are filtered and expanded through a gas turbine to generate the remaining 20 to 25 percent of the plant output and to supply the compressed air for the PCFB combustor. A schematic process flow diagram of the Pyroflow PCFB process and subsystems is shown on Figure 1.

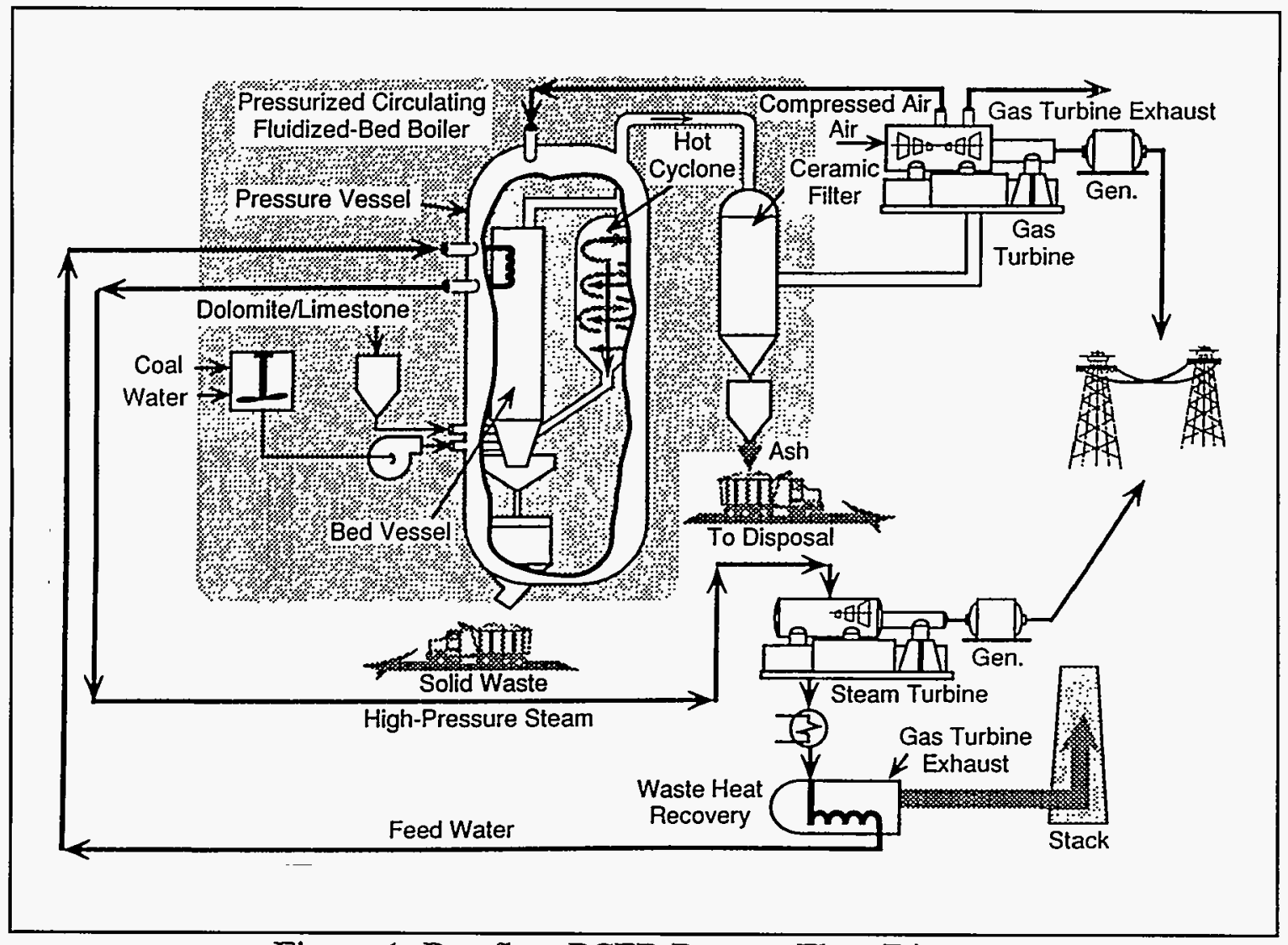

Figure 1: Pyroflow PCFB Process Flow Diagram

Coal and sorbent are supplied to the PCFB combustor as a paste using a technology similar to that used in pumping concrete. The materials are injected into the PCFB combustor with the assistance of a steam atomizer to distribute the particles. As combustion occurs, sulfur is absorbed by the sorbent and the finer particles of coal and sorbent become entrained with the flue gas and enter the hot cyclone. Here, the majority of the particles are collected and returned to the combustor through the loop seal. The finer ash particles continue with the hot gases to the 
ceramic filter where final removal of particulate is achieved. The cleaned flue gas is expanded through the gas turbine, and remaining useful heat in the exhaust is recovered in a conventional heat recovery unit. The clean exhaust is released to the stack.

The compressor section of the gas turbine provides pressurized air to the PCFB pressure vessel. The air flows from the top to the bottom of the vessel, cools the vessel and internal components, and enters the PCFB combustor through the grid at the bottom of the combustor and at various locations above the grid. The fuel and sorbent materials are mixed with the air in the combustor where combustion occurs at a temperature of about $1,600^{\circ} \mathrm{F}$. Because of the continuous mixing throughout the PCFB combustor, this temperature is relatively constant from the bottom to the top of the combustor. Heat is recovered from the hot flue gases in a similar manner to conventional boilers to generate steam which is used to power the steam turbine.

\subsection{Gas Turbine Island}

The gas turbine island includes the gas turbine, generator, and hot valves. The compressor section on the gas turbine provides pressurized combustion air for the PCFB combustor. The gas turbine generator set includes all necessary auxiliaries, including the lube oil system, startup motor, gear box, silencers, filters, controls, instruments, and PCFB system interface.

The hot clean gases from the ceramic filter are expanded through the expander section of the gas turbine to produce 20 to 25 percent of the power generated. This provides a net increase in station capacity and provides the combined cycle effect which produces an additional improvement in the net plant heat rate of 8 to 15 percent.

The use of hot gas cleaning technology in the PCFB process allows a great deal of flexibility in the selection of a gas turbine. This flexibility arises because a particulate free hot gas stream permits many commercially available turbines to be adapted to the PCFB process. The most significant modification is an adaptation of the turbine casing to allow extraction of air from the compressor section of the turbine for external firing in the PCFB and the return of hot flue gases to the expander section.

High temperature valves for safety and control are provided upstream of the gas turbine. These valves provide diversion of airflow for shutdown in the event of a loss 
of load on the generator. In the event that a shutdown is required, these valves will quickly isolate the turbine and PCFB.

Evaluation of a topping combustor was performed. Results indicate the addition of the topping combustor to the DMEC-1 project does not provide the desired peaking capacity, does substantially increase the capital cost of the project, and does increase the cost of generation because of increased fuel cost.

\subsection{Balance-of-Plant}

The DMEC-1 project will require the refurbishment or replacement of major equipment. Turbine Generator 6 will be refurbished to serve as the steam powered turbine generator. The existing turbine generator is rated at a nominal $65 \mathrm{MW}$. It is a nonreheat turbine that is designed to operate at $1,250 \mathrm{psig}$ and $950^{\circ} \mathrm{F}$ with a steam flow of up to $561,000 \mathrm{lb} / \mathrm{h}$. The generator is hydrogen-cooled (up to $30 \mathrm{psi}$ hydrogen pressure) and operates at 3,600 rpm.

In addition, the existing coal handling facilities, structure, and some of the major auxiliaries, such as the boiler feed pumps, condensate pumps, circulating water pumps, fuel oil, condensate and surge tanks, deaerator, feedwater heaters, auxiliary heat exchangers, etc., will most likely be refurbished with some components being replaced. Since the design life of the repowered facility will be 30 years, an examination of refurbishment versus new equipment will be performed to determine which option has the lowest life-cycle cost. New equipment includes the main stepup transformer; main auxiliary and reserve auxiliary transformers; a modern digital control system; instrumentation for the PCFB; the gas turbine; new electrical distribution system and switchgear; new demineralizer; modernization of the steam turbine and generator auxiliaries; retubing of the condenser and some of the feedwater heaters; replacement of the cooling towers; and new motors and pumps for cycle support processes.

\subsubsection{Coal Feed System}

Figure 2 provides a schematic of the paste coal feed system. In the DMEC-1 demonstration plant, the coal feed system will be designed for 100 percent redundancy. Each gravimetric feeder will be located at the bottom of one of the existing coal silos. Two sets of gravimetric feeders will each feed one coal/water paste preparation and mixing system, which in turn will feed two individual paste feed pumps. 


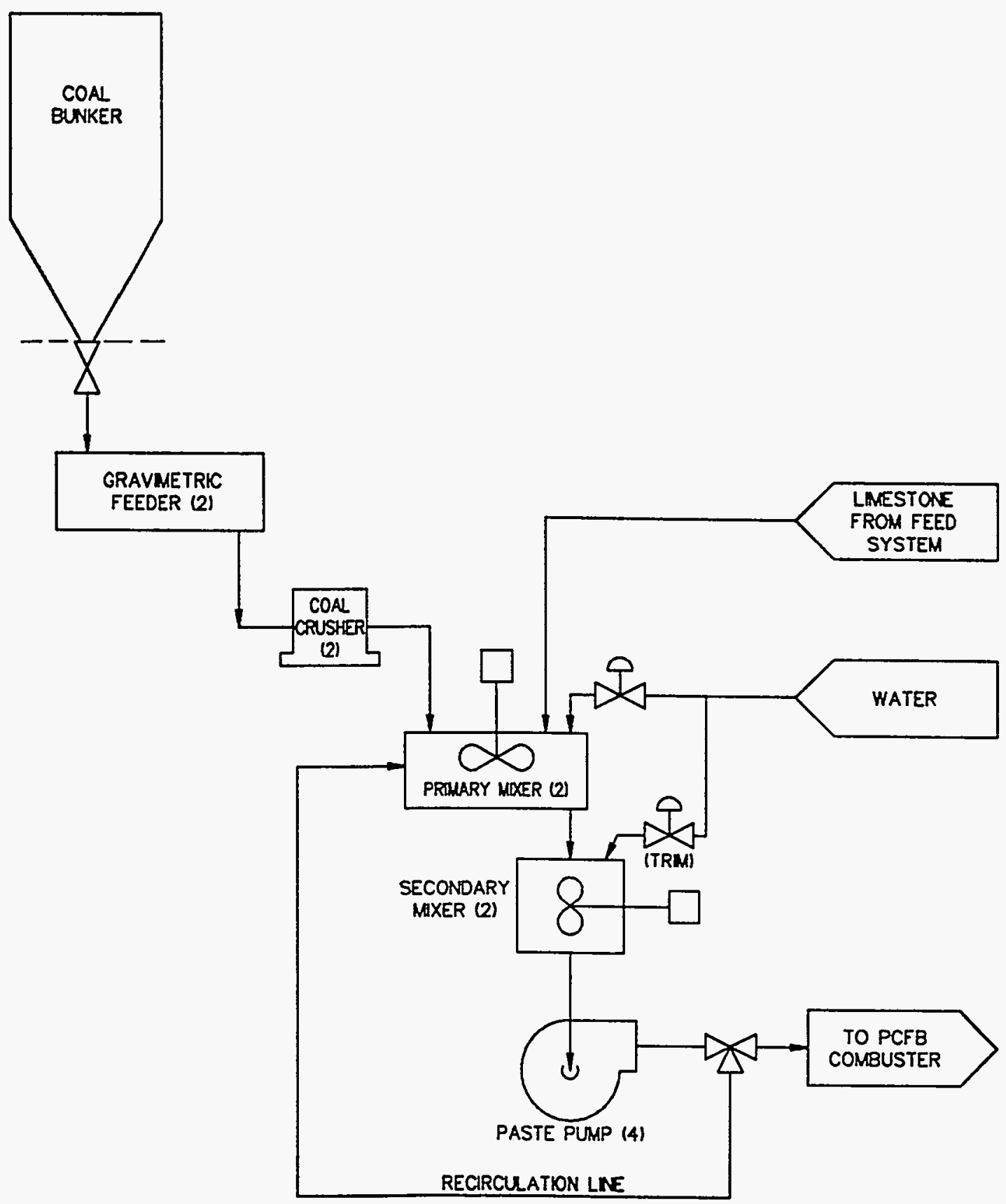

Figure 2: Schematic of Fuel Feed System 
In the paste preparation system, coal crushed to $1 / 4$ " by 0 and water will be combined in a two-stage mixer to a net surface moisture content of 20 to 25 percent. This moisture level is just sufficient to allow efficient and reliable performance of the paste pumps. Feeding of both subbituminous coals with as-received moisture contents in the range of 25 to 30 percent and lower moisture bituminous coals will be an important aspect of the demonstration. Testing of these fuels has been performed at the Ahlstrom PCFB testing facility in Karhula, Finland, to evaluate fuel feeding considerations.

The piston type pumps employed for paste feeding are conventional technology; the pumps typically are utilized for pumping solid water slurries in applications such as concrete handling. Paste pumping systems have been evaluated extensively at the Ahlstrom PCFB testing facility, and in other pressurized fluidized bed systems, such as the Grimethorpe plant in England and American Electric Power's Tidd Plant.

The paste pumps will pressurize the paste mixture to about 180 to 200 psig to force the paste through the feed lines, which penetrate the pressure vessel and carry the paste into the PCFB combustor. As the fuel enters the combustor, a steam atomizer will be used to assist distribution of the fuel throughout the lower combustor region.

One of the advantages of the PCFB technology over pressurized bubbling beds, is the enhanced mixing that occurs in the circulating fluidized bed (CFB) system. This enhanced mixing means the PCFB requires fewer fuel feed points. In this project, the boiler will be designed to achieve full load when operating on two fuel feed points, $1 / 3$ to $1 / 10$, the number typically required in a bubbling bed boiler. The benefits are twofold; not only is mechanical complexity reduced, but the fewer feed points allow enhanced opportunity to introduce redundancy into the design.

Limestone sorbent will be both blended with the coal and fed in a pneumatic trim system for absorption of $\mathrm{SO}_{2}$ emissions. Two new limestone silos will be added, each feeding to a paste feed train and limestone pneumatic train. Blending sorbent with the coal reduces costs by maintaining a neutral $\mathrm{pH}$ of the paste, thereby allowing the use of carbon steel components in the paste preparation system.

\subsubsection{The Limestone Feed System}

The system for blending the limestone with the fuel and injecting both as a paste will be complemented by a "trim" limestone feed system. The rate of variation in limestone injection rates through the Paste Feed System is relatively slow due to the 
residence times and inventory of paste in the paste mixing tanks. The limestone trim system is sized to allow for rapid response to variations in $\mathrm{SO}_{2}$ emissions resulting from short-term variations in fuel sulfur content, process disruptions, or other factors which might result in changes in the amount of $\mathrm{SO}_{2}$ generated. Figure 3 provides a schematic of the limestone feed system. This system is comprised of two sets of 100 percent capacity limestone gravimetric feeders withdrawing limestone from the two storage silos. Each feeder will discharge into a surge silo from which the limestone is either conveyed to the paste system or directed into a lock hopper system. In the lock hoppers, the sorbent will be pressurized using air from the discharge of the gas turbine compressor that has been boosted in pressure by a motor driven compressor. The pressurized sorbent will then be conveyed pneumatically to the combustor.

The lock hoppers will be accessible for on-line maintenance. A separate sand lock hopper will be provided which can load one charge of bed inventory into the combustor for initial startup.

\subsubsection{PCFB Hot Loop}

The circulating fluidized bed hot loop is the heart of the Pyroflow PCFB process technology. The hot loop is shown on Figure 4. It is comprised of the PCFB combustor, the hot cyclone, the loop seal return, and the water and steam-cooled heat transfer surfaces.

Coal and sorbent pressurized by their respective feed systems are fed into the lower PCFB combustor which, under full load operating conditions, will operate at about 160 psig. The design of the PCFB combustor will apply the same proven principles used to design atmospheric Pyroflow CFB units.

The combustor uses membrane wall construction. In the demonstration project, natural circulation will provide water from the drum through the downcomers to cool these waterwalls, ensuring cooling even during shutdown conditions. The lower section of the combustor, where the solids density will be highest, is lined with abrasion resistant refractory. This refractory provides for protection of the lower combustor walls from erosion during operation. It also provides a region for safe slumping of the bed during a shutdown condition.

In the refractory lined zone of the combustor, the fuel and sorbent are mixed with air provided by the compressor section of the gas turbine. About 60 percent of the air fed to the combustor is primary air which is injected through the grid in the 


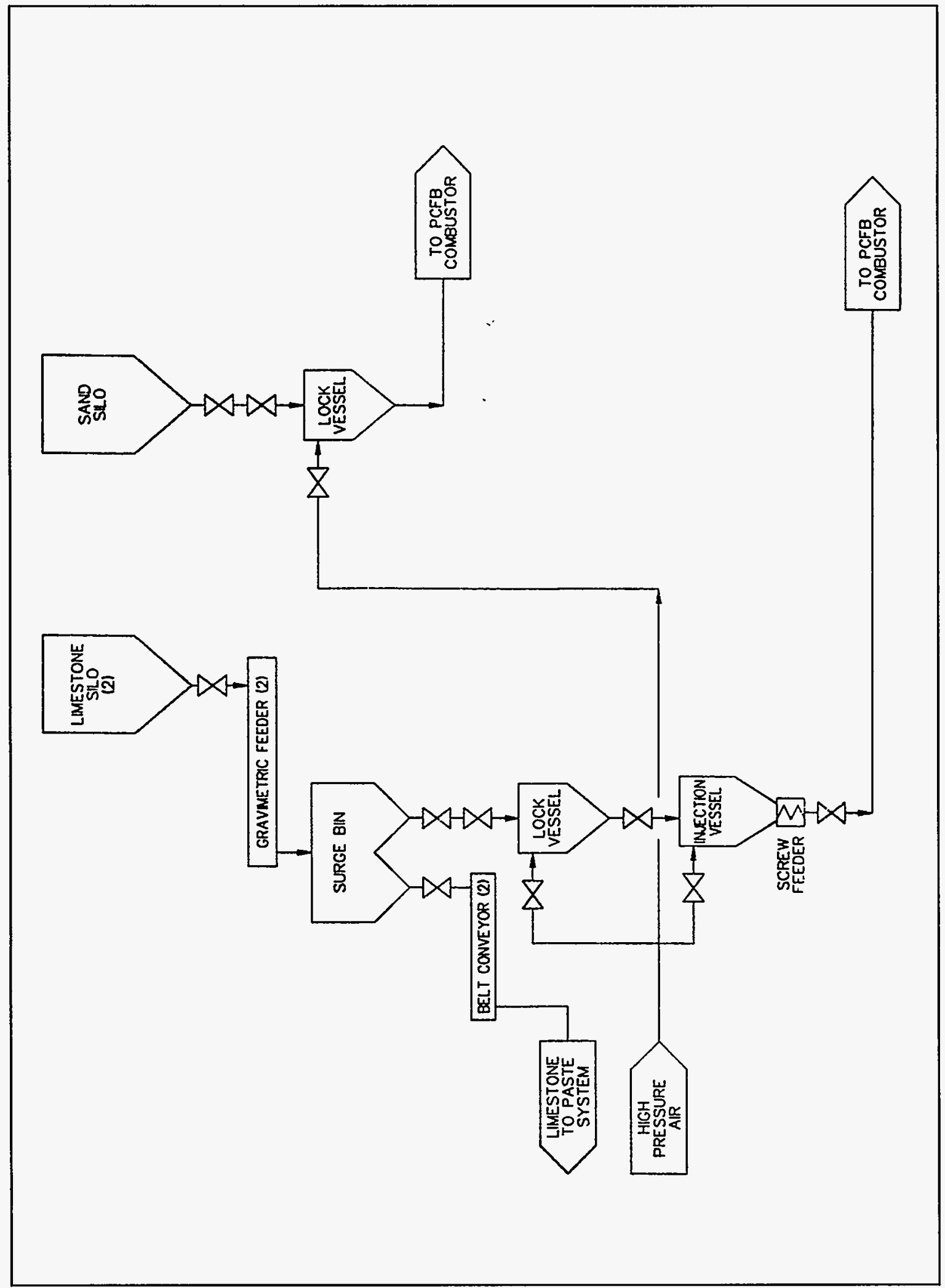

Figure 3: Schematic of Limestone/Sand Feed System 


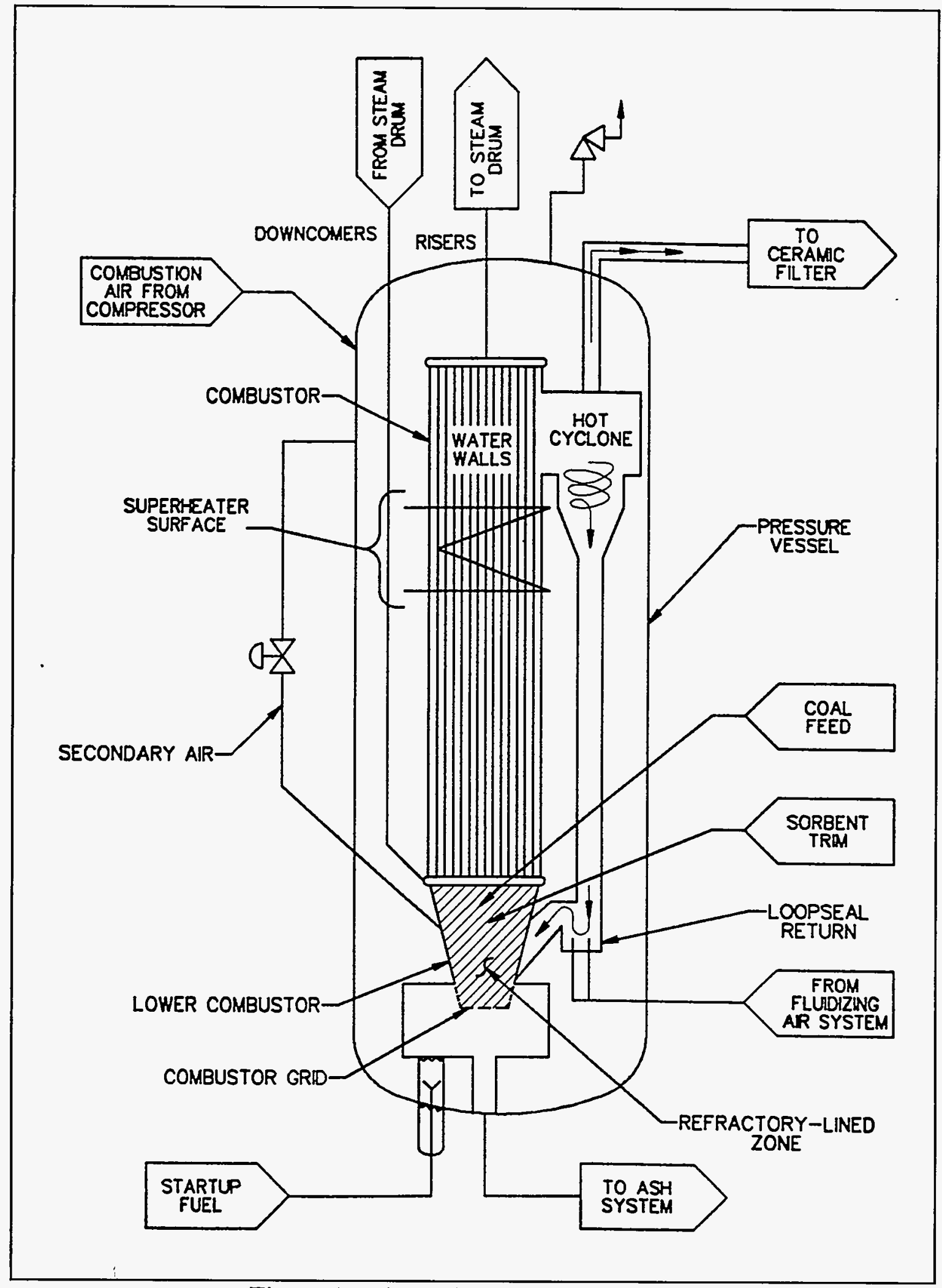

Figure 4: Schematic of PCFB Hot Loop 
lower combustor. This air provides for the fluidization and mixing of the fuel and sorbent. The startup burners will be fired with No. 2 oil or natural gas during a cold startup condition to preheat the combustor and ceramic filter to a temperature sufficient for stable firing of coal.

The remaining 40 percent of the air to the combustor is added as secondary air at points above the combustor grid. The reasons the combustion air is separated into primary and secondary air streams are as following:

- To provide combustor temperature control.

- To promote staged combustion for minimization of the formation of $\mathrm{NO}_{\mathrm{x}}$.

- To promote solids mixing and circulation.

- To supply air for continuous fines combustion in the upper part of the combustion chamber.

- To improve load following operation.

As opposed to the bubbling pressurized fluidized beds which require variation in the inventory of solids within the fluidized bed to increase or reduce load, load variations in the PCFB process can be accomplished by varying the fuel input rate and the ratio of primary to secondary air. The result is a variation in the heat release rate and in the profile of the density of solids in the combustor. A change in the solids density profile will change the heat transfer coefficient throughout the combustor. This allows relatively easy adjustment in the rate of heat removal. This procedure is used during startup, for load following, and for combustor temperature control in atmospheric CFBs and will be applicable to the PCFB.

Unlike bubbling pressurized fluidized bed systems, there are no submerged heat transfer surfaces in the lower combustor of the PCFB process. Due to excellent solids circulation and mixing throughout the combustor, the temperature distribution throughout the PCFB combustor is relatively uniform. Thus, the entire height of the combustor is available for locating steam superheating surfaces. The risk of erosion of heat transfer surfaces is reduced in the PCFB as these surfaces are located well above the dense solids zone of the combustor and are constructed of flat sided double omega tubing. In this upper region, particles are smaller, and their impact frequency on the surfaces of the combustor is relatively low. This also dramatically simplifies the operation of the PCFB versus bubbling bed designs.

"Double omega," a special kind of superheating tubing, has been successfully utilized in operating atmospheric Pyroflow installations for the identical purpose. Double omega surface is effective because it presents a flat plane to the flow of hot 
gases and solids in the combustor. Leading and trailing edges of the double omega platens are protected with applied erosion protective materials. Spray type desuperheaters will be utilized for control of the superheat temperature.

The superficial velocity in the PCFB combustor is about 13 to $15 \mathrm{ft} / \mathrm{s}$ (4 to $5 \mathrm{~m} / \mathrm{s}$ ), typical of velocities in atmospheric circulating fluidized bed (ACFB) installations. The operating temperature is in the range of $1,600^{\circ} \mathrm{F}$. As the fuel is combusted and the sorbent is reacted with gaseous $\mathrm{SO}_{2}$, smaller particles are entrained in the upward flow of flue gases. The hot gases and entrained solids leave the combustor and enter the hot cyclones where most of the entrained particles are collected and recirculated to the combustor through the loop seals. In the demonstration plant design, two hot cyclones will be utilized, each handling one half of the combustor exit gas flow. In the loop seals, a small amount of air is injected to refluidize the collected solids and return them to the combustor. This pressurized air is provided by a separate compressor.

The collection of entrained particles in the hot cyclones and the recirculation of those solids through the loop seals to the combustor promotes long solids residence time at the combustion temperature. The long residence time and the mixing effects of the fluidized suspension ensure high combustion efficiencies for a wide range of fuels and promote the effective mixing of the fine sorbent with the fuel for efficient $\mathrm{SO}_{2}$ removal. The $\mathrm{SO}_{2}$ emission results are equivalent to or surpass the capabilities of coal gasification while the calcium utilization results are superior to ACFB performance due to the different nature of the chemical reactions that take place.

In ACFB boilers, limestone is first calcined to calcium oxide before it reacts with $\mathrm{SO}_{2}$ to form calcium sulfate. The sulfation reaction is prevented from going to completion by the relatively impervious layer of calcium sulfate that forms around the unreacted particles of calcium oxide. This layer impedes the diffusion of $\mathrm{SO}_{2}$ through to the unreacted core of the particle.

Under PCFB conditions, the chemical reactions are quite different. The high partial pressure of carbon dioxide $\left(\mathrm{CO}_{2}\right)$ in the combustion chamber inhibits the calcination reaction from proceeding. The calcium carbonate $\left(\mathrm{CaCO}_{3}\right)$ is converted directly to calcium sulfate $\left(\mathrm{CaSO}_{4}\right)$ without an intermediate step by the following reaction:

$$
\mathrm{CaCO}_{3}+\mathrm{SO}_{2}+1 / 2 \mathrm{O}_{2} \rightarrow \mathrm{CaSO}_{4}+\mathrm{CO}_{2}
$$

051394 
$\mathrm{CO}_{2}$ is expelled from the individual limestone particles in parallel with the diffusion of $\mathrm{SO}_{2}$ and oxygen $\left(\mathrm{O}_{2}\right)$ into the particle. This reaction mechanism maintains the porous nature of the particle and the sulfation reaction proceeds further towards completion than in the case of ACFBs. Thus, when compared to ACFBs, PCFBs will require lower calcium/sulfur $(\mathrm{Ca} / \mathrm{S})$ molar ratios for the same given $\mathrm{SO}_{2}$ removal requirement.

The by products of sulfur collection, $\mathrm{CaSO}_{4}$ (and $\mathrm{CaCO}_{3}+\mathrm{MgCO}_{3}$ ) mixed with coal ash, are inert and can be disposed by conventional means. Typically, the solids are delivered to the disposal site in dry form and are wetted after placement. Any unreacted calcium oxide in the waste will set up and form an impermeable solid waste. Leachate tests have been performed on waste PCFB ashes, and they qualify as nonhazardous.

Depending on sorbent reactivity and operating conditions, the anticipated calcium to sulfur ratio for the PCFB process is expected to be in the range of 1.5 for 90 percent sulfur removal. The actual ratio will be confirmed by pilot tests.

\subsubsection{Pressure Containment}

A steel pressure vessel encloses the PCFB hot loop. The combustor and hot cyclones are suspended from the top of the vessel. Platforms and necessary ladders for access to these components are mounted inside. Adequate space is provided in the vessel to allow for removal of all combustor internals and to provide room for routine maintenance. External platforms will allow for access to the vessel, external equipment, and instrumentation.

\subsubsection{Ceramic Filter}

Flue gas which leaves the hot cyclones proceeds to the hot ceramic filter where entrained fly ash and sulfur laden sorbent are collected. The use of hot gas cleanup technology means that no further particulate cleanup is required to meet specifications for protection of the gas turbine against erosion or for emissions to the atmosphere.

\subsubsection{Ash Depressurization and Cooling System}

The hot ash is removed at two locations, i.e., from the PCFB hot loop and from the ceramic filter. These systems are currently designed as water-cooled pressurized screw coolers and lock hoppers. The rate of ash removal from the combustor is 
controlled to maintain adequate bed inventory. Both systems include 100 percent redundancy to promote high plant availability. As an alternative to mechanical cooling with water-cooled screws, nonmechanical ash cooling systems are also under evaluation.

\subsubsection{Hot Gas Piping}

The hot gas piping systems interconnect the compressor to the combustor and the ceramic filter to the turbine. These systems will employ commercially available materials and components. The primary design consideration is interfacing the various components (the combustor pressure vessel, hot filter, hot valves, and gas turbine) with proper tolerances for connections, expansion, and pressure loads. Coaxial or lined piping will be utilized consistent with the inlet and outlet configurations of the gas turbine.

\subsubsection{Heat Recovery Economizer}

The heat recovery economizer (HRE) is utilized to recover remaining useful heat in the exhaust gases from the gas turbine. Following expansion of the clean pressurized gases in the gas turbine, the $800^{\circ} \mathrm{F}$ flue gas is ducted to the heat recovery economizer which has a conventional finned-tube design. Surfaces and flue gas temperatures will be kept above the condensation dew point to avoid corrosion. The heat recovered in the HRE will be utilized for feedwater heating. Optimal integration of this heat in the existing cycle will be accomplished by passing some of the existing feedwater heaters with a major portion of the feedwater flow.

\subsection{Integration with Existing Facilities}

In this project, an existing boiler will be replaced to repower an existing steam turbine. The steam turbine, manufactured by Westinghouse, was placed in service in 1954 and is rated at a nominal $65 \mathrm{MW}$. It is designed for superheated steam at $1,250 \mathrm{psig}$ and $950^{\circ} \mathrm{F}$ at a flow rate of $561,000 \mathrm{lb} / \mathrm{h}$. The associated generator is a hydrogen cooled machine rated at a nominal $65 \mathrm{MW}$. As a part of the project, the turbine generator subsystems will be refurbished or replaced as needed. Figure 5 shows how the PCFB will be integrated into the existing systems.

In the existing cooling system, it is anticipated that the condenser will be refurbished and the cooling tower system will be replaced. The condensate system will be refurbished with some components such as the condensate pump motors 


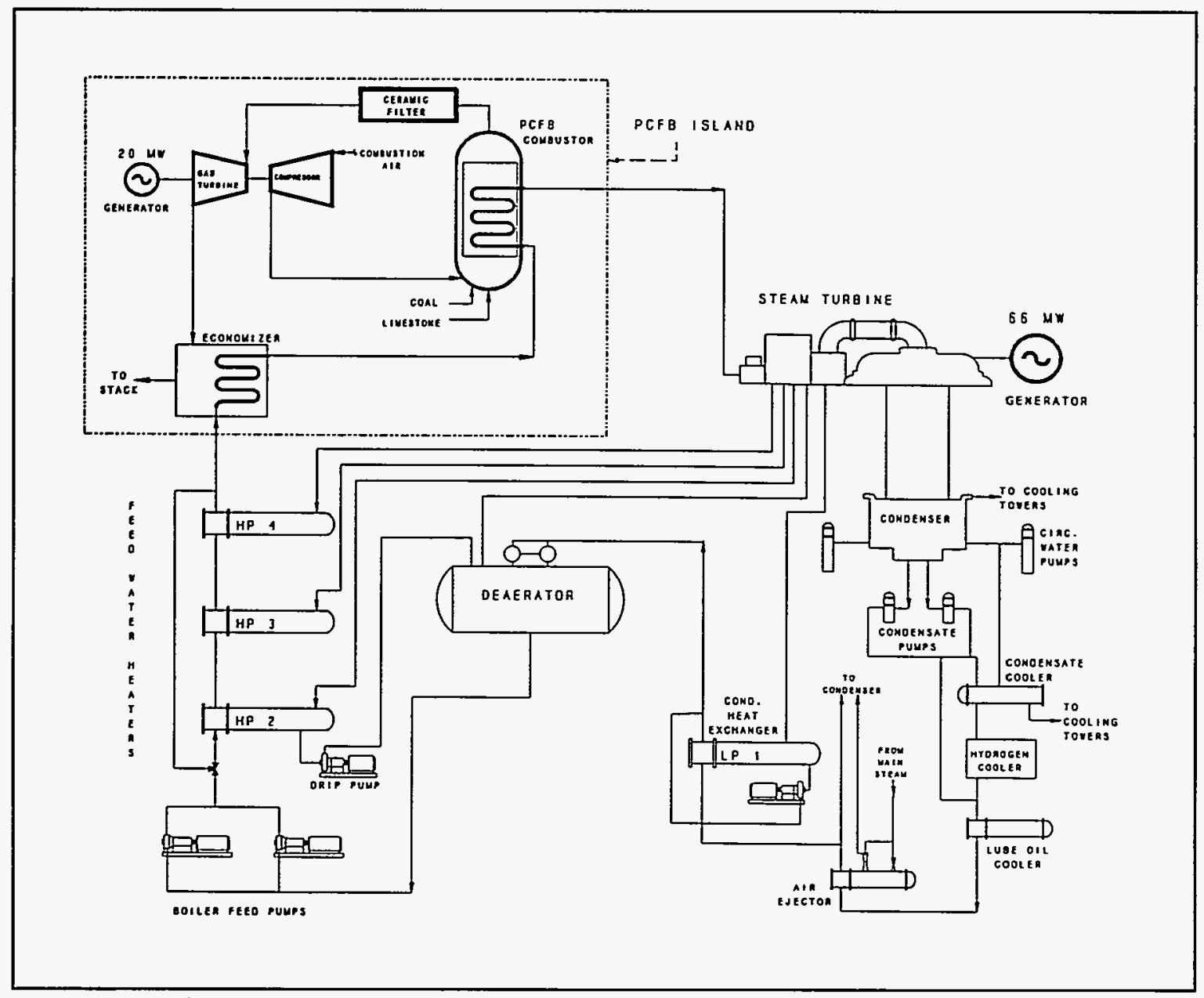

Figure 5: PCFB Connection to Existing Equipment at DMEC

requiring replacement.

Extensive refurbishment and modification to the feedwater heater system is necessary. Use of existing feedwater heaters will be evaluated as the detailed steam cycle design is completed.

Existing coal handling facilities and rail facilities will be reused with some modifications to replace deteriorated equipment and to upgrade it to meet the design requirements of the repowered plant.

As much of the existing buildings and structures will be modified and reused as possible for the repowered plant. Figure 6 is an artist's rendering of how the completed structure will appear. 


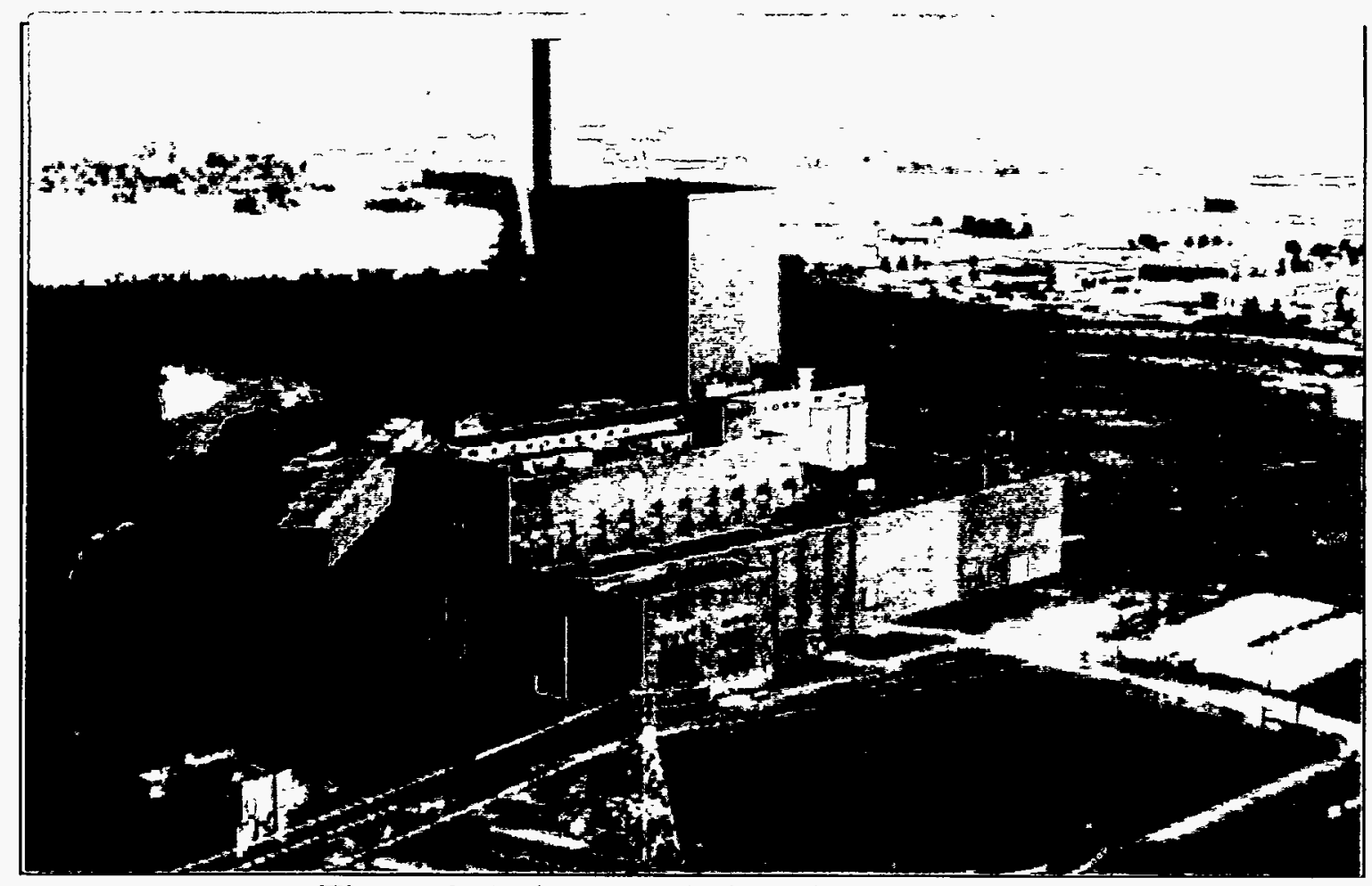

Figure 6: Artist's Rendering of New Structure 


\subsection{New Systems}

This section will cover plant systems which are the major parts of the new technology of the Pyropower Corporation PCFB combustion and power generation system: the PCFB boiler, the gas turbine, and the hot side filtration system. This section will also discuss the topping combustor and why it was not included in this project.

\subsection{Pressurized Circulating Fluidized Bed Steam Generator}

\subsubsection{Steam Generator}

The PCFB steam generator produces superheated steam at 1,300 psig and $955^{\circ} \mathrm{F}$. The designed capacity of the PCFB unit is $522,061 \mathrm{lb} / \mathrm{h}$ of steam, which will produce approximately $66,482 \mathrm{~kW}$ (gross). An additional $20,400 \mathrm{~kW}$ will be produced by the gas turbine which acts as an expansion unit in the $133.4 \mathrm{psig}, 1,600^{\circ} \mathrm{F}$ flue gas stream.

3.1.1.1 Major Components. The PCFB steam generator system consists of the following major components:

- Combustion pressure containment vessel operating at 156.7 psig.

- Steam drum.

- Primary, secondary, and tertiary superheater sections.

- Heat recovery economizer.

- Flue gas/ash cyclone separators and loop seals.

- Coal bunkers, gravimetric feeders, and crushers.

- Bed ash and fly ash screw coolers, and lock hoppers.

- Coal fuel paste, and primary and secondary mixers.

- Coal fuel paste pumps.

- Natural gas startup burners.

- Limestone sorbent silo, bins, and volumetric feeders.

- Sorbent lock hoppers.

- Startup sand silo and injection vessel.

3.1.1.2 Description. A simplified process flow diagram for the boiler feed and steam circuit of the steam generator system is shown on Figure 7.

Water from the boiler feedwater system is delivered to a control valve which modulates the flow to maintain the water level in the steam drum. Modulation of the valve is controlled by the distributed control and information system (DCIS) (see 


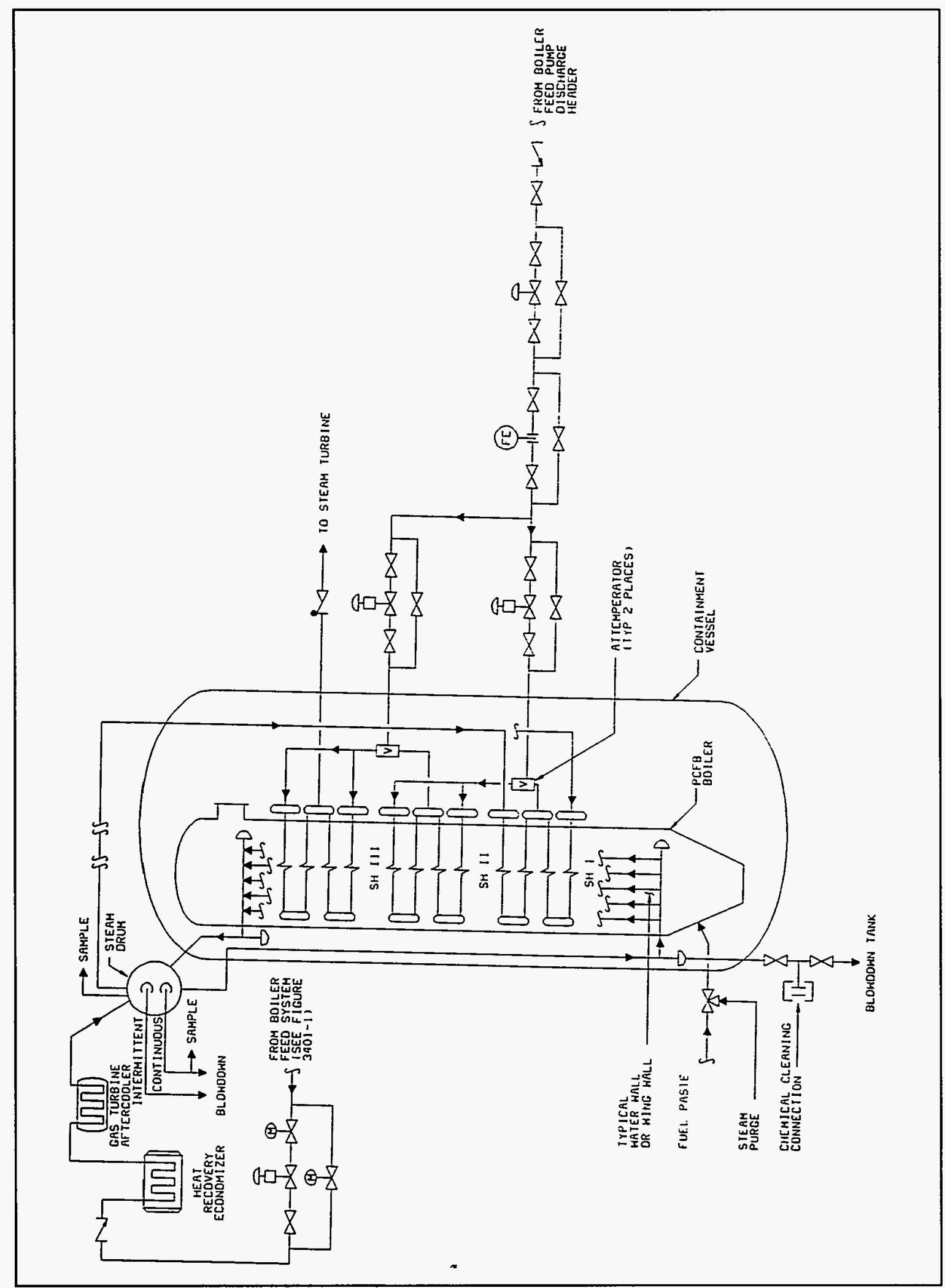

Figure 7: Boiler Feed and Steam Circuit Process Flow Diagram 
section 4.6) and is based on steam drum water level and steam and boiler feedwater flow rate signals. The boiler feedwater at the control valve is approximately 1,570 psig and $260^{\circ} \mathrm{F}$. The boiler feedwater then flows through a heat recovery economizer which extracts heat from the gas turbine exhaust flue gas to increase the temperature of the boiler feedwater to $503^{\circ} \mathrm{F}$ at a pressure of $1,560 \mathrm{psig}$. The boiler feedwater then passes through the gas turbine aftercooler where heat extracted from the gas turbine compressor exhaust gas increases the temperature of the boiler feedwater to $550^{\circ} \mathrm{F}$ at a pressure of $1,550 \mathrm{psig}$. Boiler water circulates from the steam drum down through a series of downcomers to the wingwalls and lower headers which supply the waterwalls of the combustion chamber. Heat absorbed from the combustion chamber by the waterwalls and wingwalls generates a mixture of saturated steam and water which is returned through riser pipes to the steam drum. Saturated steam from the steam drum flows down through a downcomer to headers supplying evaporative wing wall sections. In the wing wall sections, heat transferred from the flue gas increases the temperature of the water to above the boiling point at the steam drum pressure. When the water is returned to the steam drum, steam is formed. Saturated steam from the steam drum passes in series through three superheater stages. Boiler feedwater at $1,570 \mathrm{psig}$ and $260^{\circ} \mathrm{F}$ is supplied to spray attemperator units at the discharges of the first two superheater sections to control the temperature of the main steam exiting the steam generator.

A simplified process flow diagram for the steam generator system combustion air and flue gas flow path is shown on Figure 8. Ambient air is drawn through an air intake filter and a temperature control unit by the gas turbine unit compressor section. The gas turbine compressor increases the pressure and temperature of the air to $157.7 \mathrm{psig}$ and $675^{\circ} \mathrm{F}$, respectively. The compressed air from the compressor passes through a gas turbine aftercooler which decreases the pressure and temperature to $156.7 \mathrm{psig}$ and $600^{\circ} \mathrm{F}$, respectively. This compressed air stream then branches to supply primary combustion air through the PCFB bed, secondary combustion air into the containment vessel and then from the containment vessel to the above bed zone in the PCFB, and supply air to the booster air compressor and filter purge air compressor units. Flue gas from the PCFB exits through two parallel cyclone separators where centrifugal forces separate large entrained particles from the gas stream. The collected particulate is returned to the PCFB combustion zone. Flue gas containing fine particulate matter (fly ash) exiting the steam generator is passed through two parallel ceramic filters for removal of the fly ash. Clean flue gas 


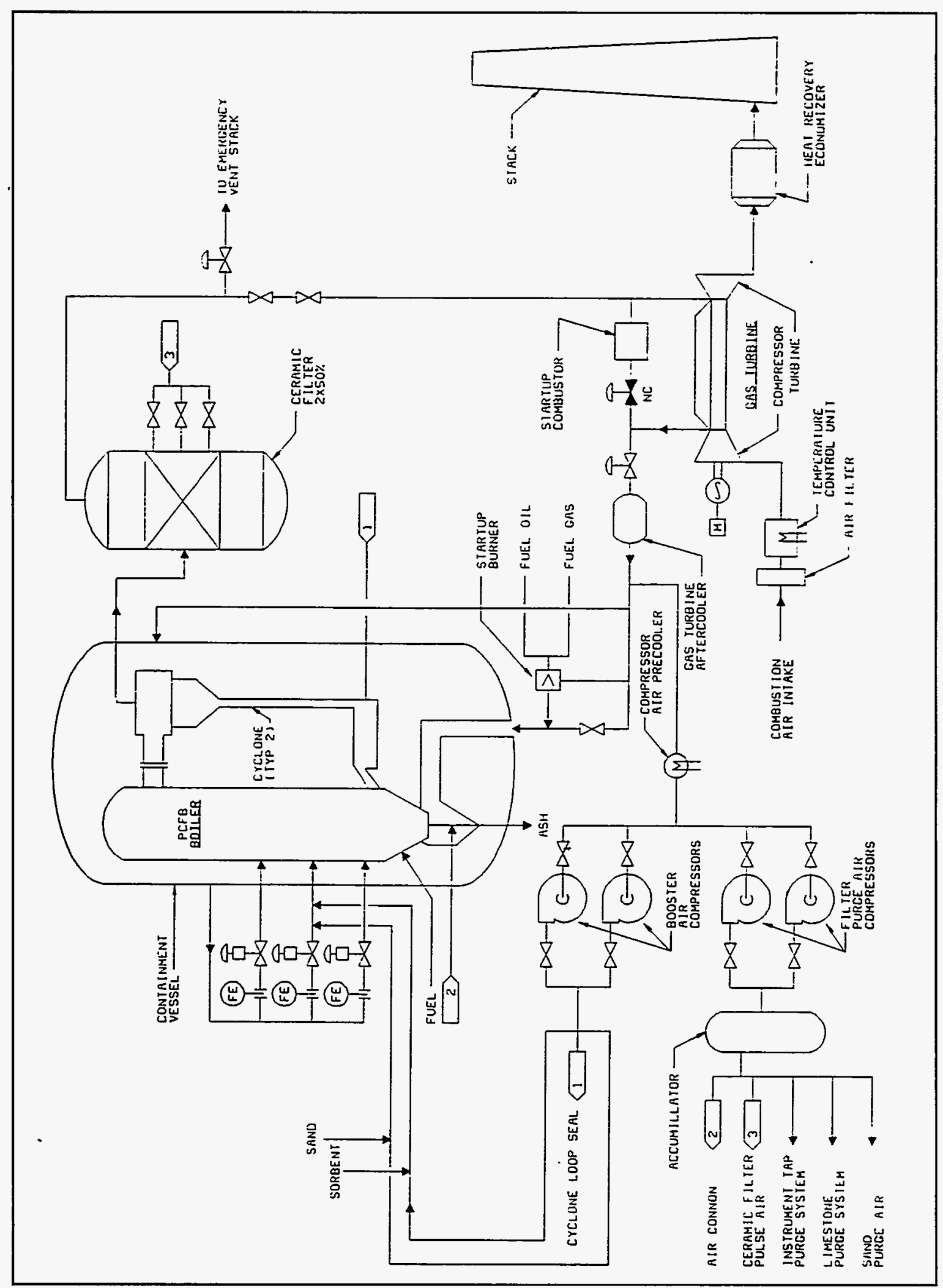

Figure 8: Combustion Air and Flue Gas Flow Process Flow Diagram 
is then discharged through the gas turbine where the flue gases expand from 133.4 psig and $1,600^{\circ} \mathrm{F}$ to $0.22 \mathrm{psig}$ and $822^{\circ} \mathrm{F}$. The flue gas then passes through the HRE to heat incoming boiler feedwater, then enters the stack at near 0 psig and $300^{\circ} \mathrm{F}$. An emergency vent stack is provided between the ceramic filters and the gas turbine to depressurize the PCFB and ceramic filters during a unit trip or shutdown.

A simplified process flow diagram for the steam generator system fuel supply circuit is shown on Figure 9. The coal feed system consists of two parallel circuits to crush coal and produce a coal-limestone-water paste fuel for the PCFB. Coal is fed from a coal bunker by gravimetric feeders to crushers. The speed of the gravimetric feeders, and hence the coal feed rate, is controlled by a signal from the DCIS which is based on steam demand. The crushers discharge into the primary paste mixers which mix the coal particles ( $1 / 4^{\prime \prime}$ by 0 ) with limestone and water to form a paste. The primary paste mixers discharge to secondary paste mixers which complete the mixing process. The product from the secondary mixers is discharged to the feed hoppers of the paste pumps. The paste pumps are positive displacement, piston type pumps whose speed can be varied by a hydraulic drive system. Coal paste flow to the PCFB is modulated by varying the speed of the piston pump. Coal paste flow is modulated based on a signal from the DCIS system relating to steam demand to inject coal paste fuel into the bed of the PCFB, or recirculate the coal paste fuel to the secondary paste mixers. A simplified process flow diagram for the steam generator system sorbent feed circuit is shown on Figure 10.

The sorbent feed system supplies limestone to the PCFB to control the sulfur dioxide emissions from the steam generator to within regulatory limits. Limestone sorbent is fed from limestone storage silos by gravimetric feeders to a surge silo. The speed of the gravimetric feeders is controlled by a signal from the DCIS which is based on steam demand. The control signal is biased based on the sulfur dioxide content of the flue gas measured at the stack. The surge silos discharge by gravity to a lock vessel or screw conveyors which feed limestone to the primary paste mixers (see Figure 10). The screw conveyors are equipped with variable speed drives which respond to a signal from the coal gravimetric feeders to proportion the limestone feed rate to the coal feed rate. Because the limestone storage silos, gravimetric feeders, and surge silo operate at atmospheric pressure, the limestone feed to the injection vessel must pass through a lock vessel which isolates the equipment operating at atmospheric pressure from the PCFB gas side pressure of 156.7 psig. 


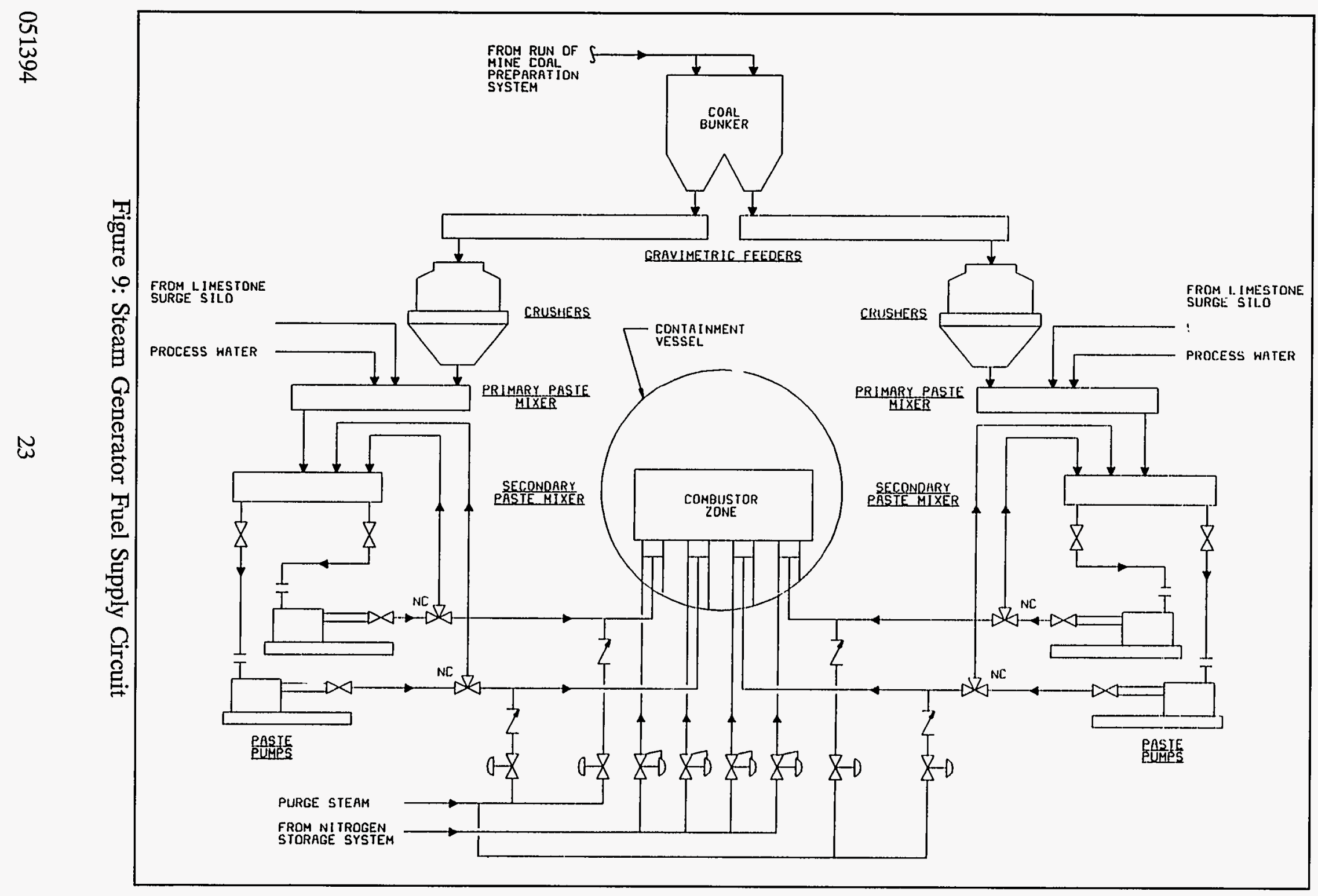




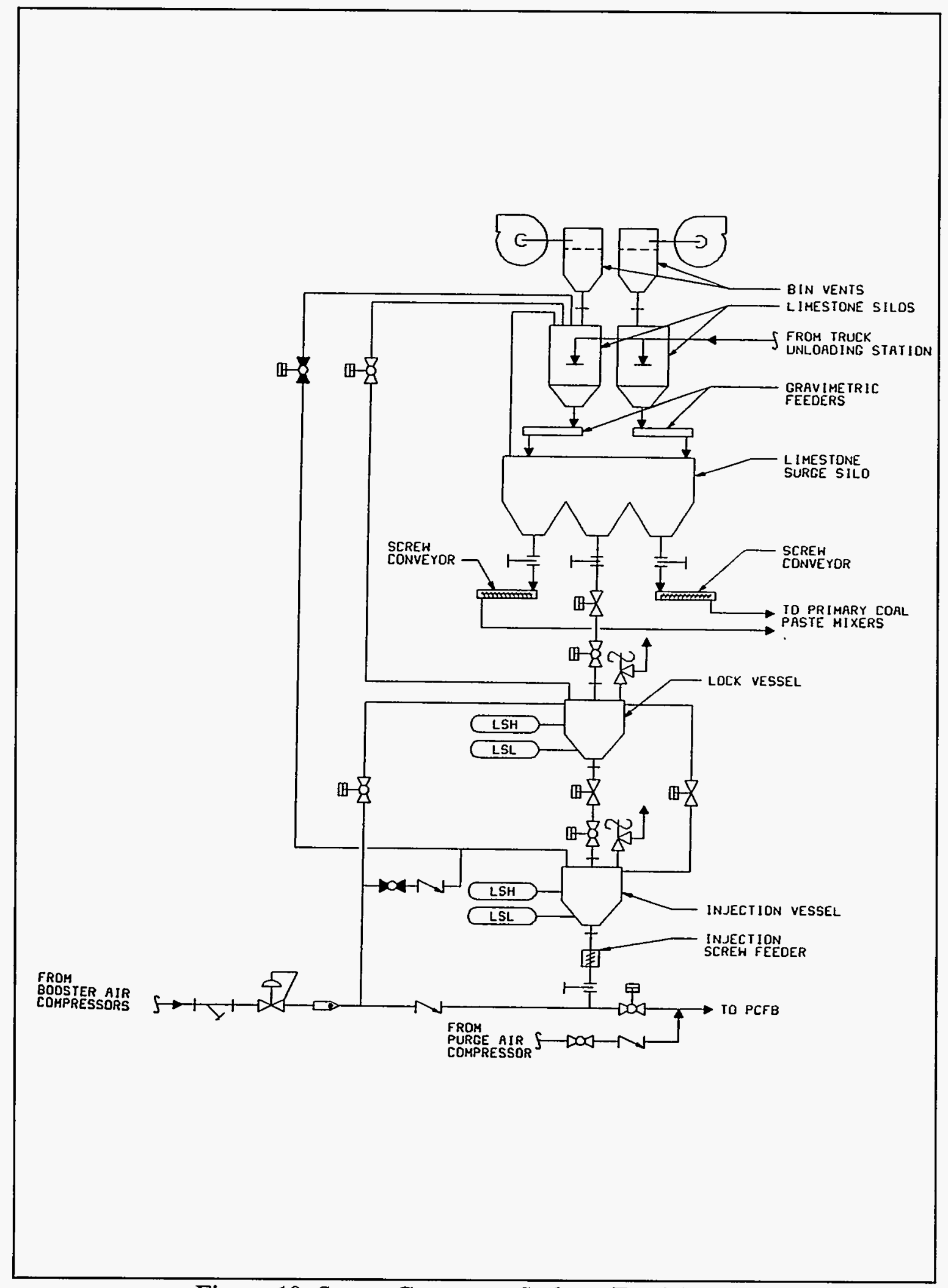

Figure 10: Steam Generator Sorbent Feed System 
To fill the lock vessel, the limestone chute and vent valves between the injection vessel and lock vessel are closed. The lock vessel is then pressurized with air. When the pressure is equalized, a valve in the limestone feed chute between the injection vessel and the lock vessel is opened and limestone flows by gravity to the injection vessel. When a high level switch in the injection vessel is satisfied, the valve in the supply chute and vent line close and the fill cycle of the lock vessel is repeated. Limestone is fed from the injection vessel by a positive displacement screw feeder into a pneumatic conveying system which injects the limestone into the PCFB through secondary combustion air ports above the bed.

Operation of the vent valves and supply chute valves is interlocked to prevent two valves in series from opening at the same time. The cycle is based on demand. Feed to an injection vessel is initiated when the limestone level in an injection vessel drops below a low level switch in the injection vessel. Likewise, a fill cycle for a lock vessel will not occur until the limestone level in a lock vessel drops below a low level switch.

The lock vessel/injection vessel cycle described for the limestone system is similar to the ash removal systems, although the ash system vent valve is arranged differently than the limestone system.

A simplified process flow diagram of the steam generator system sand feed circuit is shown on Figure 11. Sand, with specific properties, is used for the initial charge of bed material and for occasional bed makeup requirements. Sand is fed from the pressurized injection vessel to the PCFB using sand system transport air. To fill the injection vessel, a level switch closes an isolation valve in the sand transport piping between the injection vessel and PCFB and closes a valve in the sand transport air supply line to isolate the injection vessel. A vent valve in a vent line between the injection vessel and the sand silo bin vent opens to reduce the pressure in the injection vessel to atmospheric. An isolation valve in the sand chute between the injection vessel and sand silo opens, and sand flows by gravity into the injection vessel.

A simplified process flow diagram of the steam generator system ash removal circuits are shown on Figure 12. Bottom ash is discharged from the bottom of the PCFB by two parallel water-cooled screw conveyors. Fly ash is discharged from the bottom of each of two ceramic filters by two parallel water-cooled screw conveyors. The ash removal screw conveyors discharge into lock vessels which discharge into ash hoppers. The ash hoppers discharge to a pneumatic ash conveying system which 


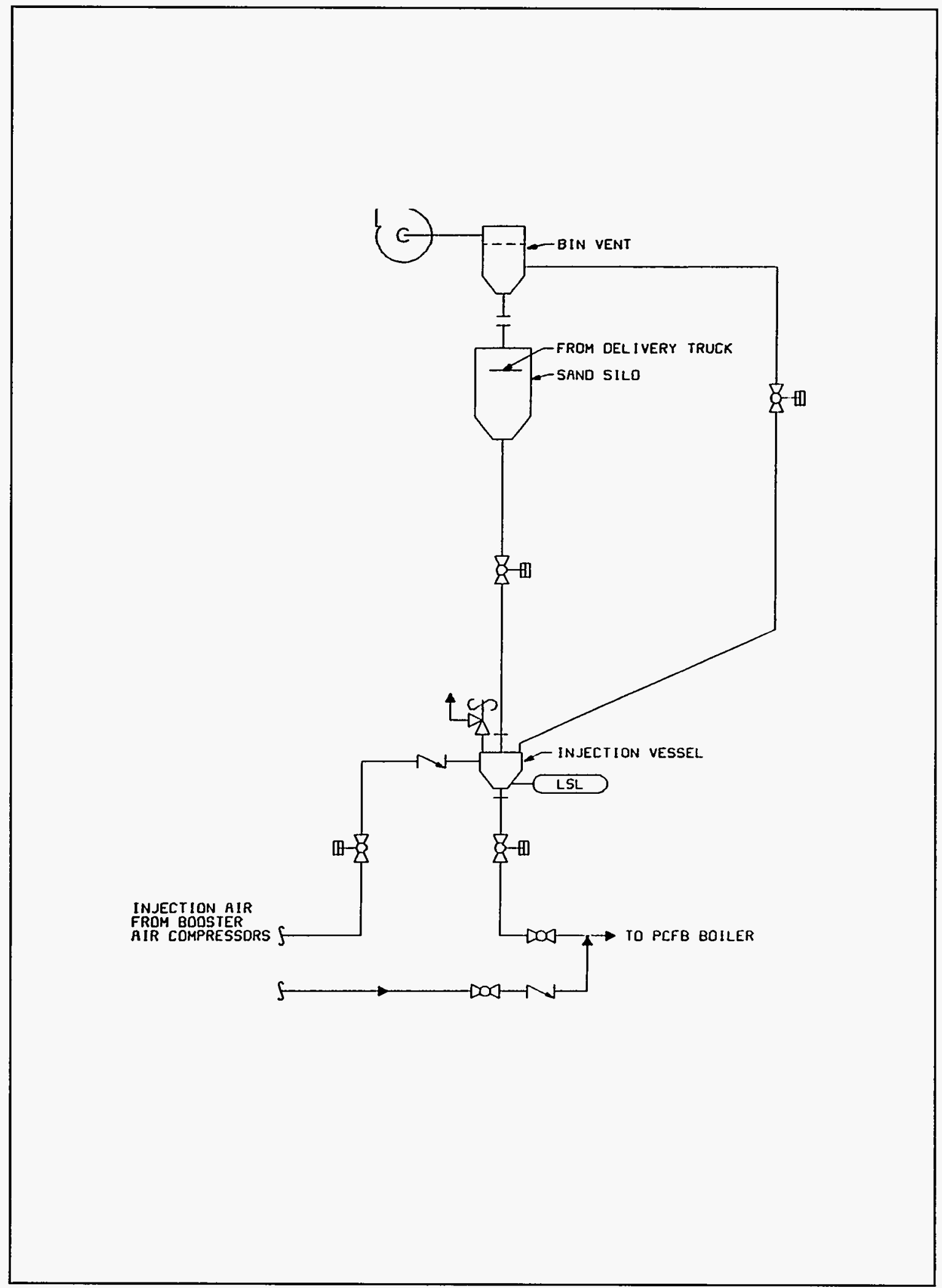

Figure 11: Steam Generator Sand Feed Circuit 


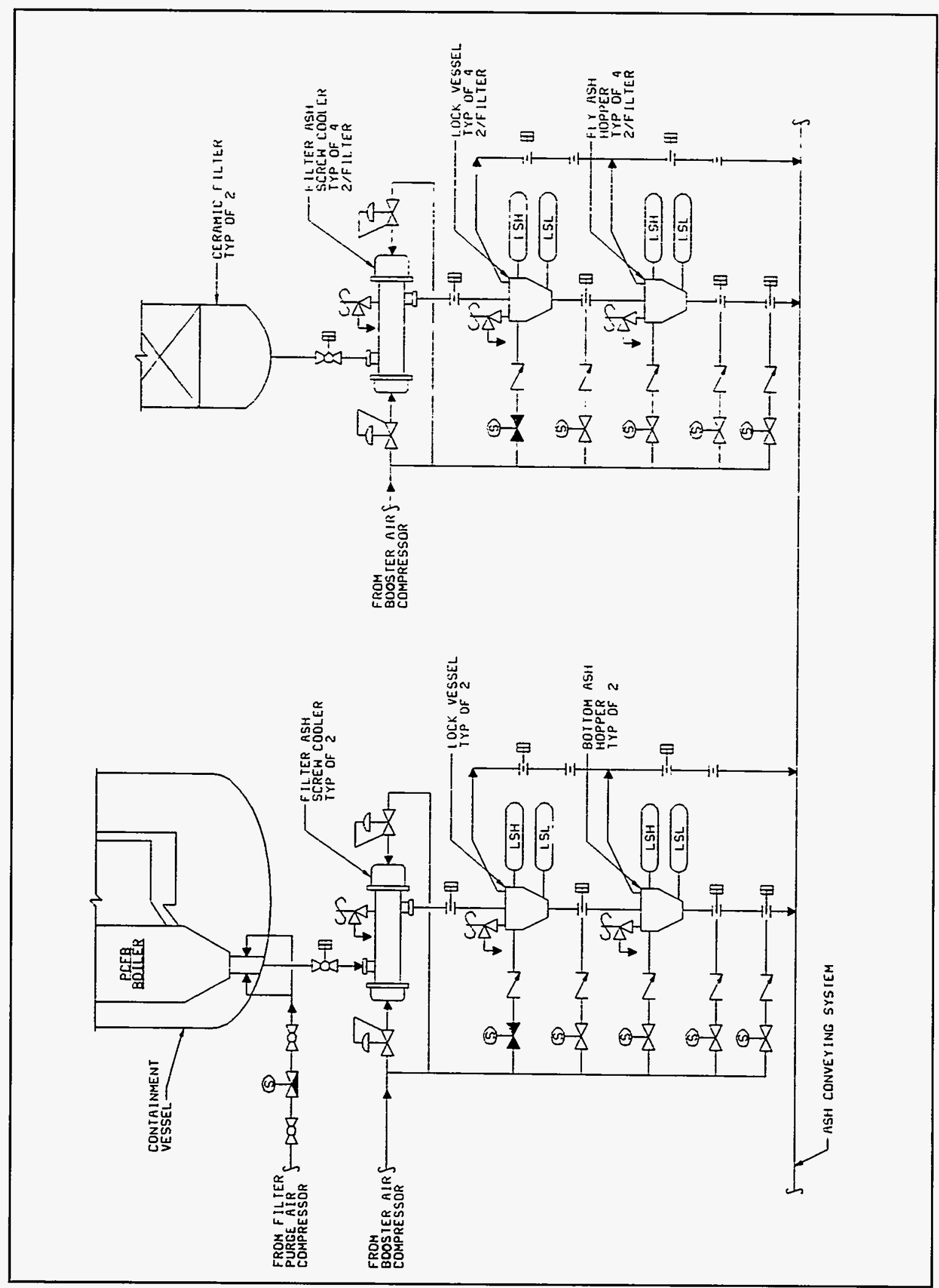

Figure 12: Steam Generator Ash Removal Circuit 
delivers the ash to an ash storage silo.

3.1.1.3 System Design Requirements. The steam generator and its components including boiler external piping will be designed, furnished, and installed in accordance with the latest applicable requirements for power boilers of the ASME Boiler and Pressure Vessel Code--Section 1, Rules for Construction of Power Boilers, Part PG, latest edition and addenda; ANSI/ASME Power Piping B31.1.

The steam generator will be designed to deliver $522,061 \mathrm{lb} / \mathrm{h}$ of steam at 1,300 psig and $955^{\circ} \mathrm{F}$, when supplied with feedwater at $260^{\circ} \mathrm{F}$ while burning the specified western subbituminous coal.

Internal high temperature zones in the PCFB containment vessel will be equipped with internal refactory and insulation. External areas of these pressure vessel zones will remain uninsulated to minimize metal shell temperatures. Low metal temperatures increase the allowable design stress which decrease the required thickness of the containment vessel wall. Expanded or perforated metal barriers will be installed at locations requiring personnel protection from elevated temperature.

The PCFB pressure vessel and associated safety relief devices will be designed, constructed, and tested in accordance with the latest edition of ASME Boiler and Pressure Vessel Code--Section VIII, Pressure Vessels. Pressurized air and gas piping will be designed, furnished, and installed in accordance with ANSI/ASME Power Piping B31.1 and 31.13.

\subsubsection{Gas Turbine Generator and Excitation}

The gas turbine generator and excitation system converts the mechanical energy of the gas turbine to electrical energy. In addition, the system provides manual and automatic control of the generator terminal voltage and electrical protection of the generator, exciter, and generator step-up transformer.

The generator will be of the open air-cooled type. The generator will be supplied as part of a packaged gas turbine generator set. The gas turbine generator set will be a stationary, heavy-duty, industrial single-shaft unit designed to operate at 3,600 rpm. A standard unit will be modified as required to operate with the PCFB. The generator will be designed for a gross electrical output of $20.4 \mathrm{MW}$.

The excitation system will be of the brushless excitation type with the voltage regulator controlling the generator output by adjustment of the excitation at the brushless main exciter. A permanent magnet pilot exciter provides power to the voltage regulator which controls the stationary field of the ac exciter. The alternating 
current exciter field produces current in the exciter rotating armature. This output is rectified by the silicon diodes in the rectifier wheel. The resulting direct current is carried through leads inside the shaft to the rotating generator field. Three-phase output is produced in the ac generator stator by the rotating generator field. The potential transformers and the current transformer provide generator voltage and current information to the voltage regulator.

The gross output of the generator will be $20.4 \mathrm{MW}$ at a 0.85 power factor. The generator will be designed to deliver three-phase electricity at 60 hertz when operated at the design speed of 3,600 rpm. The nominal terminal voltage of the generator will be 13,800 volts.

The generator will be designed to operate satisfactorily in parallel with the steam turbine generator.

\subsection{Hot Side Gas Filtration}

A key feature of the PCFB is the hot side gas filtration system. Flue gas which leaves the hot cyclones proceeds to the hot ceramic filter, where entrained fly ash and sulfur laden sorbent are collected. The use of hot gas cleanup technology means that no further particulate cleanup is required to meet specifications for protection of the gas turbine against erosion, or for emission to the atmosphere. Several hot side filtration systems are currently being evaluated. The filter system which will be used for this demonstration project will be presented in a future report.

\subsection{Topping Combustor}

The project originally included a natural gas fired topping combustor located upstream of the gas turbine gas inlet. The purpose of the topping combustor was to heat the cleaned exhaust gases from $1,600^{\circ} \mathrm{F}$ to approximately $2,000^{\circ} \mathrm{F}$ before they were expanded through the turbine to provide the project with peaking capability (typically called "1-1/2 generation" cycle when natural gas is used to increase the temperature). A detailed analysis of the DMEC-1 design with and without a topping combustor was performed in association with Westinghouse. The results indicated that incorporation of the topping combustor resulted in a significant increase in capital cost without a comparable increase in station power output. Plant heat rate was improved with topping but the fuel cost increased due to the large price differential between coal and natural gas in the proposed plant's locale. When the topping combustor was turned off, plant heat rate increased and net power output decreased 
relative to a plant designed without topping. The reasons for this were complex but primarily involved the differing amounts of turbine cooling air required for a $1,600^{\circ} \mathrm{F}$ turbine inlet temperature relative to a $2,000^{\circ} \mathrm{F}$ inlet temperature and the higher boiler excess air required for the topping combustor compared to a design without topping. The greater the amount of cooling air for a given gas turbine and the higher the boiler excess air, the less air is available for coal combustion and therefore for steam generation. 


\subsection{Balance-of-Plant}

This section will discuss the major balance-of-plant systems which support the new systems.

\subsection{Limestone and Sand Handling}

\subsubsection{Limestone and Sand Receiving}

The function of the limestone and sand receiving system is to receive and unload pulverized limestone and sand from tank type trucks and transfer it to the limestone and sand storage system. The limestone and sand receiving system will be capable of unloading one 25 ton truck in approximately 30 minutes at the rate of 50 tons per hour. The simplified flow diagram of the limestone and sand handling system is shown on Figure 13.

Limestone will be delivered pulverized to a size of 1,000 microns ( 0.04 inches). Pulverized limestone will be delivered to the site by 25 ton tank type trucks. Sand will also be delivered to the site by the same type trucks. A positive displacement mechanical blower will be located in the new gas turbine building near the truck unloading area. A pneumatic transport line will connect the truck discharge line to the limestone storage silos and sand silo. The mechanical blower will provide the volume and pressure of motive air required to convey the material to the limestone and sand storage system.

Transported material (pulverized limestone or sand) will be discharged from the transport line into each of three silos, located in the new Steam Generator Building.

Each silo will be equipped with a vent filter to release the displaced air and vent the conveying air to the atmosphere. The pulverized limestone or sand removed from the vented air will be discharged back into the corresponding silo.

Pulverized limestone will be discharged from each silo through the rotary air lock into the paste preparation component of the steam generator system.

Sand will be discharged from the sand silo through the rotary air lock into the pneumatic line connecting the sand silo with a boiler.

Each silo will be an open-ended cylinder with a constant percent reduction cone welded to a common skirt plate. Each pulverized limestone silo will be designed for 400 ton capacity. The total capacity of two pulverized limestone silos will be 800 tons, which is approximately equal to a 4 day supply of limestone based on a maximum consumption rate of 8.2 tons per hour for the high sulphur content Iowa 


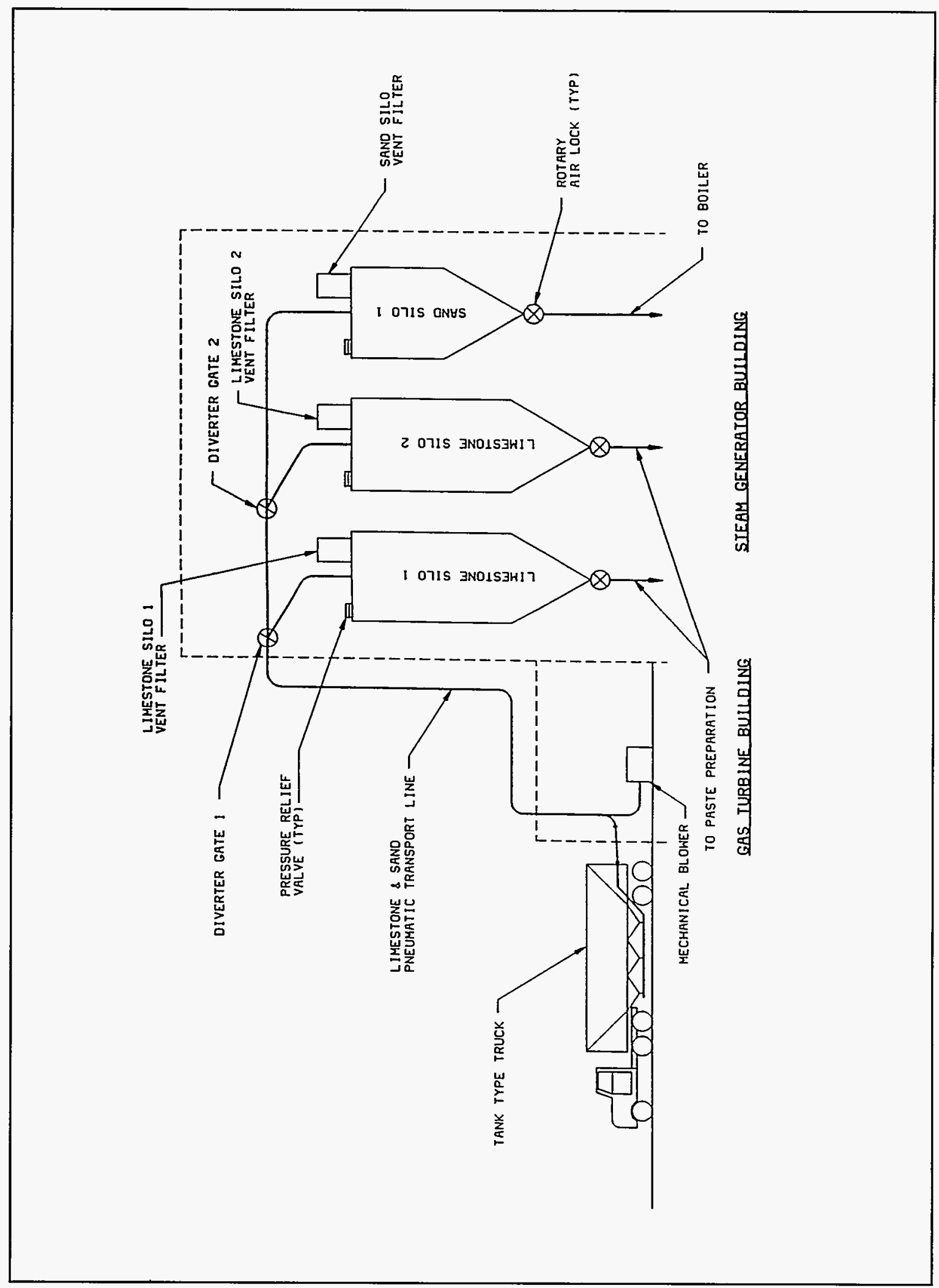

Figure 13: Limestone and Sand Handling System Flow Diagram 
coal. A 4 day storage capacity will allow the plant to continue to run without material delivery during a 3 day weekend.

The sand storage silo will be sized for approximately 60 ton capacity, which is adequate for two boiler startups.

\subsection{Coal Handling}

This section will cover the coal handling system at the DMEC- 1 site. The coal handling system will be modified from the existing system to modernize the system. The coal handling process flow diagram can be found on Figure 14. The systems covered in this section include coal receiving, coal stockout and reclaim, coal bunker fill and crushing, and coal dust control.

\subsubsection{Coal Receiving}

The function of the coal receiving system will be to receive and unload coal from railcars or trucks. The existing truck unloading hopper will be modified and used for the occasional local Iowa coal unloading and also as a coal reclaim hopper. Truck unloading hopper description is included in the coal stockout and reclaim system.

Coal will be delivered to the site by rail. Unloading of the fifty 100 ton bottom discharge cars will be accomplished by indexing the cars over a receiving hopper with a locomotive and dumping the car's contents. The coal dumped into the receiving hopper will be fed through two discharge openings onto a new 84 inch wide collecting conveyor/feeder 3 , which will transfer the coal to the coal stockout and reclaim system or via conveyor 7 to the bunker fill and crushing system. The existing car shaker will be refurbished in order to assist coal unloading operations in the winter. A railroad track scale will also be provided.

Coal delivered by 20 ton truck will be dumped into the truck unloading and reclaim hopper and fed through a discharge opening onto a collecting conveyor/ feeder 5, which will transfer the coal to the coal stockout and reclaim system. The design of the coal receiving system will focus on upgrading the system to allow 100 ton cars unloading at the rate of 500 tons per hour.

\subsubsection{Coal Stockout and Reclaim}

The coal stockout and reclaim system provides for the transfer of coal to and from the coal storage pile. It also provides a means for transferring coal from the pile to the coal bunker fill and crushing system. Coal from the coal receiving system 


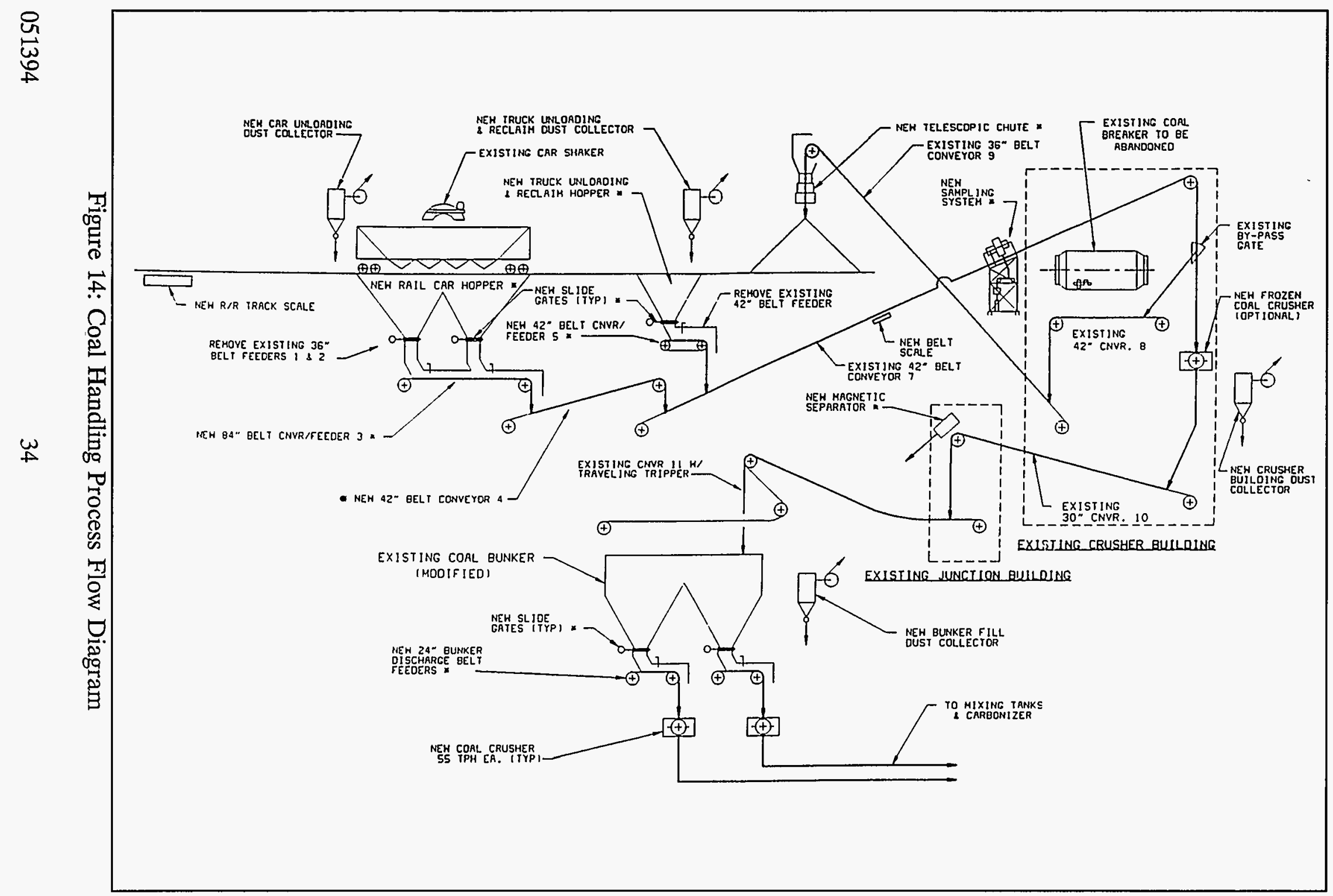


will be transferred via new conveyor 4 and existing conveyor 7 to the existing crusher building. The existing coal crusher will be abandoned, and the existing coal crusher building will be utilized as a coal transfer building. Coal from conveyor 7 will be discharged onto conveyor 8 and transferred via conveyor 9 to a stockout pile or diverted to a bunker fill and crushing system.

Coal reclaimed through the reclaim hopper will be discharged onto a collecting conveyor/feeder 5, which will transfer it to conveyor 7. Coal from conveyor 7 will be conveyed to the coal bunker fill and crushing system.

A new telescopic chute will be provided at the head end of conveyor 9 to minimize dust emission during the operation.

The coal stockout conveyors will be sized to match the 500 tons per hour car unloading rate. The coal reclaim conveyors will be sized at 200 tons per hour to reclaim approximately 1,300 tons of coal needed for 24 hours of plant operation in one 8 hour shift.

\subsubsection{Coal Bunker Fill and Crushing System}

The coal bunker fill and crushing system transports the coal from the coal receiving system or from the coal stockout and reclaim system to the top inlet of the plant coal bunkers and crushes it to an acceptable size. Coal conveyed to the existing coal crusher building (coal transfer building) will be discharged onto the existing conveyor 10 and transferred via the existing bunker fill conveyor 11 equipped with a traveling tripper into the modified coal bunker.

The existing bunker will be divided by the retaining wall to form a coal storage section with a capacity of approximately 1,300 tons, adequate for 24 hours of storage based on the controlling western coal burn rate of 54.35 tons per hour. The existing bunker discharge openings will be converted into two bifurcated hoppers to improve the coal flow and provide a smooth transition to the new coal crushers located at the coal bunker discharge outlets.

Each crusher will have a capacity of reducing 2 inch by 0 inch coal to a minus $1 / 4$ inch size at the rate of 55 tons per hour.

The coal bunker fill conveyors will be sized with a capacity of 200 tons per hour to deliver approximately 1,300 tons of coal necessary for 24 hours of plant operation in one 8 hour shift. 


\subsubsection{Coal Dust Control}

The function of the coal dust control system is to minimize the escape of coal dust generated by the coal handling system into the atmosphere. The system will employ induced draft, filter bag units, enclosed in a stiffened plate housing. Dustladen air will be directed to the inlet plenum at the dust collector units through ductwork. After passing through the filter bag, the filtered air will be drawn from the units by induced draft fans and discharged to the atmosphere. Dust collected by the filter bags, as well as dust precipitated within the unit, will fall into hoppers which form the unit housing bottoms. Dust will be conveyed from the hoppers to screw conveyors, chutes, or bucket elevators for return to the conveying system. A rotary vane type air lock valve will be provided at each point where hopper-collected dust is transferred from the vacuum condition in the collectors to an atmospheric region. A flow diagram showing the location of dust collection equipment is shown on Figure 14.

\subsection{Ash Handling}

\subsubsection{Bottom Ash}

Bottom ash from the PCFB steam generator combustion process will be continuously removed from the lower zone of the pressurized circulating fluidized bed combustor. It is anticipated that 5 to 10 percent of the coal and sorbent ash will be removed as bottom ash. It is anticipated that 90 to 95 percent of the total coal and sorbent ash will leave the combustor unit as fly ash. The ash handling process flow diagram can be found on Figure 15 The bottom ash system is equipped with two full-capacity ash handling systems designed to convey bottom ash from the PCFB to a single welded steel ash silo. The two parallel systems will function as a normal operating system with 100 percent spare capability.

A water cooled, double wall trough screw conveyor will be attached to each of the two bottom ash outlets, at the pressure vessel. The conveyor assembly will cool the hot ash from $1,625^{\circ} \mathrm{F}$ to $500^{\circ} \mathrm{F}$. Each screw conveyor will discharge to two lock and ash hopper vessels, oriented in series. These gate controlled vessels will provide continuous removal of bottom ash from the pressure vessel combustor. Ash from the hoppers will be introduced to the two dilute phase ash piping and air/ash separator units, which discharge to the bottom ash yard storage silo. The airflow required to transport ash in the dilute phase system will be obtained from a normal and fullcapacity spare, rotary, mechanical exhauster, complete with centrifugal separators and 


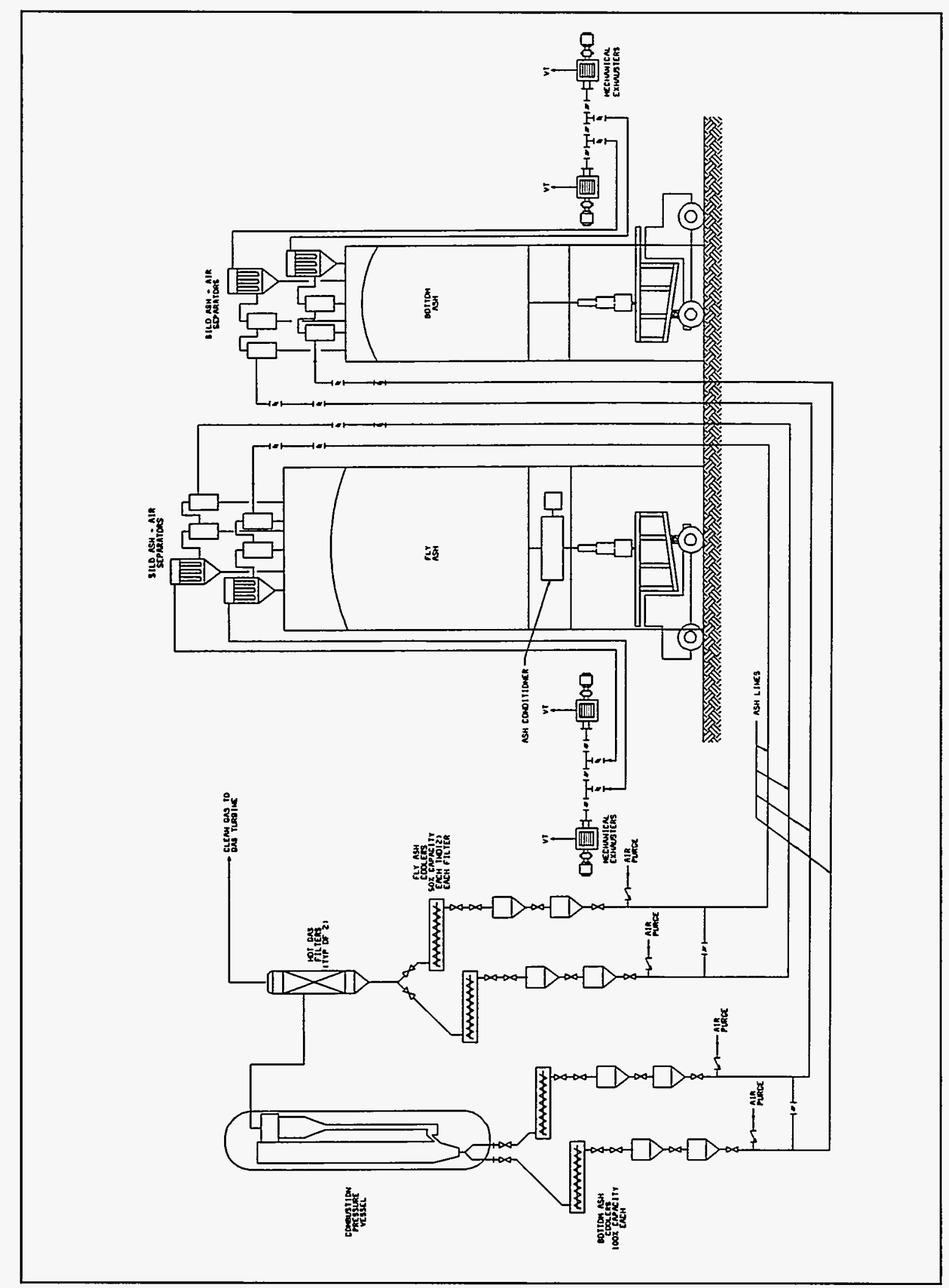

Figure 15: Ash Handling Process Flow Diagram 
bag type suction filters.

The rate of bottom ash removal is largely determined by the unit load and the sulfur and ash content of the coal. It is anticipated that the total bottom ash and sorbent removal required while burning western coal is 700 pounds per hour with a density of 92 pcf. The total bottom ash and sorbent removal for Iowa and Illinois specification coal is 3,400 and 2,200 pounds per hour, respectively. The bottom ash density of Iowa and Illinois coal is assumed to be not less than that of western coal. Should the ash be more dense, the volume of ash will be less and improve the capability of the ash handling system. The capacity for each of the two parallel bottom ash removal systems will be specified as 5 tons per hour. A yard silo 13 feet in diameter with 20 feet of vertical active storage will provide 2,700 cubic feet (125 tons) of bottom ash storage for a 14 day period, while burning western coal at MCR. While burning high ash content Illinois and Iowa coal, the yard silo will provide surge for a 4 day and a 3 day period, respectively. It appears that 3 days of storage during testing operation is acceptable, when accompanied with more frequent periods of truck hauling to the point of disposal.

\subsubsection{Fly Ash}

Fly ash from the PCFB steam generator combustion process will be continuously removed from the combustor cyclone flue gas outlet by hot gas filters. It is anticipated that 90 to 95 percent of the ash produced from the coal and limestone sorbent will be removed as fly ash.

A simplified process flow diagram of the fly ash system is also shown on Figure 15. The fly ash system is equipped with four 50 percent capacity sets of screw coolers and lock and ash hopper vessels. The four coolers and ash collection vessels will discharge into two 100 percent capacity ash handling systems designed to convey fly ash from the hot gas filters to a single welded steel ash silo. The two parallel systems will function as a normal operating system with 100 percent spare capability.

A water cooled, double wall screw conveyor will be attached to each of the four hot gas filter hoppers. The conveyor assembly will cool the fly ash from $1,625^{\circ} \mathrm{F}$ to $500^{\circ} \mathrm{F}$. Each screw conveyor will discharge to two lock and hopper vessels, oriented in series. These gate controlled vessels will provide continuous removal of fly ash from the hot gas filter. Ash from the hoppers will be introduced to the dilute phase ash piping and air/ash separator units, which discharge to the fly 
ash yard storage silo. The airflow required to transport ash in the dilute phase system will be obtained from a normal and full-capacity spare rotary mechanical exhauster, complete with centrifugal separators and bag type suction filters.

Located at the bottom of the fly ash silo will be an ash conditioner which mixes a small amount of water with ash to suppress dust prior to unloading. The fly ash then will be transported in open trucks to the disposal site.

A dry telescopic chute for use with enclosed transport trucks will be attached to the bottom of the fly ash silo. The fugitive dust from the telescopic chute will be controlled by a mechanical exhauster attached to the chute which directs the fugitive dust back into the top of the fly ash silo.

The rate of fly ash removal is largely determined by the unit load and the ash and sulfur content of the coal. It is anticipated that the total fly ash and sorbent removal required while burning western coal is 7,000 pounds per hour with a density of 75 pcf. The total fly ash and sorbent removal for Iowa and Illinois specification coal is 30,300 and 20,000 pounds per hour, respectively. The fly ash density of Iowa and Illinois coal is assumed to be not less than that of western coal. Should the ash be more dense, the volume of ash will be less and improve the capability of the ash handling system.

The capacity for each of the two parallel fly ash removal systems will be specified as 15 tons per hour. Operation with western coal can be accomplished with a single system in service. Operation with Iowa coal can be accomplished by operation with two removal systems in service. Operation with Illinois coal may be marginal with a single train but can be accomplished using two trains in parallel.

A yard silo 22 feet in diameter with 33 feet of vertical active storage will provide 12,540 cubic feet (470 tons) of fly ash storage for a 5 day period, while burning western coal at MCR. While burning high ash content Illinois and Iowa coal, the yard silo will provide surge for a 47 and 31 hour period, respectively. It appears that 31 hours of storage during testing operation is acceptable, when accompanied with more frequent periods of truck hauling to the point of disposal.

\subsubsection{Combustion Waste Storage}

The combustion waste storage system will provide onsite disposal facilities in accordance with the applicable state, federal, and local regulations, which will dispose of the combustion wastes produced during the life of the DMEC-1 clean coal technology facility. These wastes will include bottom ash and fly ash. 
Approximately 60 acres of the site have been reserved for a combustion waste disposal landfill. The actual landfill scheme that will ultimately be provided cannot be determined with certainty at this time since the selection is dependent upon permit approval by the Iowa Department of Natural Resources (IDNR).

The landfill will utilize approximately 30 acres for storage of combustion waste and 8 acres for the detention pond. Combustion waste will be hauled by truck from the combustion waste loading area to an active cell within the disposal area. Once unloaded in the active cell, the material will be spread, compacted, and graded, utilizing a dozer, a compactor as necessary, and motor grader. During spreading, combustion waste will be blended into a near homogeneous and stable mixture.

The disposal area will be developed initially as one active 12 acre cell with an estimated life of 9 years. As this cell reaches the design height, the area will be graded for proper drainage, sealed, covered with soil and topsoil, and seeded to establish grass cover. The development sequence for the entire site will be determined in final design and included in the permit application.

Runoff from the active combustion waste storage area will be temporarily impounded in the combustion waste storage detention pond where sedimentation and treatment (if required) will occur. This pond will be designed to detain the 10 year, 24 hour rainfall event. The pond effluent, meeting National Pollutant Discharge Elimination System permit requirements, will be discharged into the Army Corps of Engineer's fore bay area for pumping into the Des Moines River.

The combustion waste storage system interfaces with the bottom ash, fly ash, roads and parking, and drainage systems.

The combustion waste storage system interfaces with the bottom ash and fly ash systems at the discharge chutes from the ash silos in the combustion waste loading area. At this point, combustion waste haul trucks will be loaded with ash for transport to the active combustion waste storage area. The roads and parking interface is through the ash haul road and combustion waste loading area. The roads and parking system will provide sound operating surfaces for trucks and equipment. The grading and drainage system interface is within the active disposal area where an engineered grading and ditch system will transport storm water runoff to the combustion waste storage detention pond.

The combustion waste storage system will include an engineered landfill meeting IDNR regulations for solid waste disposal. The landfill will be developed in the existing ash disposal area, which was used during previous operation of the DMEC-1 
facility. The landfill will be developed in cells. Prior to placement of combustion waste within the active landfill area, the site will be developed to include a liner and leachate collection system. The drainage within the active area will be modified to contain and route runoff to the combustion waste storage detention pond. Landfill surface drainage will collect and transport runoff within the landfill area to the combustion waste storage detention pond by gravity flow. Runoff in excess of the volume from the 10 year storm will be allowed to overflow through a spillway into the Army Corps of Engineers' fore bay area. An allowance for siltation will be designed into the pond volume.

The landfill will be designed to contain combustion solid waste generated over a 30 year period and will be designed to meet the Iowa Administrative Code regulations pertaining to solid waste disposal. Approximately 30 acres have been designated for combustion waste storage. The landfill will be developed in cells.

The disposal method involves developing a lined landfill over a portion of the area previously used to dispose of ash during original operation of the Des Moines Energy Center. The liner and leachate control system will be designed to protect the soils, surface water, and groundwater from leachate contamination and preserve groundwater quality. Monitoring wells will be installed to verify the groundwater protection.

The landfill liner system will be composed of the following components:

- A composite liner system consisting of a low permeability soil, overlaid with a geomembrane liner, will be installed on a prepared subgrade.

- Above the liner, a leachate collection and transport system will be installed to remove ash leachate collected above the liner.

- A geotextile fabric and a protective material cover will be placed above the leachate layer.

The liner will be sloped toward the leachate collection pipes using slopes with grades between 2 and 10 percent. The leachate collection system will be designed to limit the head above the liner to no more than 1 foot. Granular drainage material containing a network of perforated pipes will be used to convey leachate to the combustion waste storage detention pond via ditches. The leachate collection system will be designed such that it may be cleaned out once every 3 years, or more frequently if necessary. Piping will be equipped with valves that enable the flow to be shut off during maintenance. 
The geotextile above the leachate layer is required to separate the granular leachate conveyance layer from the overlying protective layer, to ensure that the leachate conveyance layer retains its permeability. Granular drainage material and protective material are to be of a classification to be determined from available borrow material at the time of final design.

Geomembrane liner selection will be based on chemical compatibility with the anticipated leachate and physical properties required to function in the landfill environment.

The combustion waste storage detention pond will be designed to store at least 7 days accumulation of leachate. The leachate volume will be calculated based upon average precipitation, which is 31 inches per year.

Combustion waste hauling equipment will be sized to accommodate transfer of the maximum weekly ash production quantity during a standard 40 hour workweek.

At least one upgradient and three downgradient monitoring wells will be installed. Ground water samples from the upgradient well will be compared to downgradient wells to determine liner performance. Downgradient well spacing will be a maximum of 600 feet, and wells will be constructed as required by the IAC. Monitoring requirements will be as described in the landfill permit.

When a cell reaches its design height, a closure system will be installed. The closure will be designed with slopes between 5 and 25 percent, and will be designed to prevent ponding, inundation, erosion, slope failure, and washout. 


\subsection{Additional Systems}

\subsubsection{Main Steam}

The main steam system conveys superheated steam from the steam generator superheater outlet to the steam turbine. A simplified process flow diagram of the main steam system is shown on Figure 16.

Main steam will be produced in the steam generator and will flow from the superheater outlet header through the main steam line to the branch lines serving the steam turbine throttle valves. A main steam warming line will be provided for transporting warming steam during startup and prior to admitting steam to the turbine from the individual turbine main steam branch lines to the condenser. A control valve and a motor-operated isolation valve will be located in the warming line to control warming steam flow. A desuperheater and a spray control valve will control the temperature of the steam discharging to the condenser.

A drain pot will be provided for water removal from the main steam line. The drain pot will be located at a low point in the horizontal run as near as practical to the steam turbine. Drain lines for turbine water damage protection will be routed to the boiler blowdown tank.

Safety valves and a power relief valve will be provided for system overpressure protection. A vent line with isolation valves will be provided for venting the main steam system prior to startup after an extended outage. A connection will be provided between the two isolation valves on the vent piping for nitrogen blanketing of them main steam system during unit outages.

The main steam system will be designed to deliver steam to the high-pressure turbine at a rate which corresponds to that required for turbine operation at the valves wide open condition (522,061 lb/h at $950^{\circ} \mathrm{F}$ and $1,250 \mathrm{psig}$ ). The allowance for friction losses through the system from the superheater outlet to the high-pressure turbine throttle valves will not exceed $50 \mathrm{psi}$. The normal maximum operating pressure and temperature at the steam generator superheater outlet will be 1,300 psig (1,250 psig plus 50 psi friction allowance) and $955^{\circ} \mathrm{F}$, respectively.

\subsubsection{Steam Turbine}

The steam turbine system converts the thermal energy of the steam to mechanical energy to drive the generator, and provides extraction steam for regenerative feedwater heating, combustion air inlet temperature control, and process steam requirements. The system also includes the turbine pedestal which supports the 


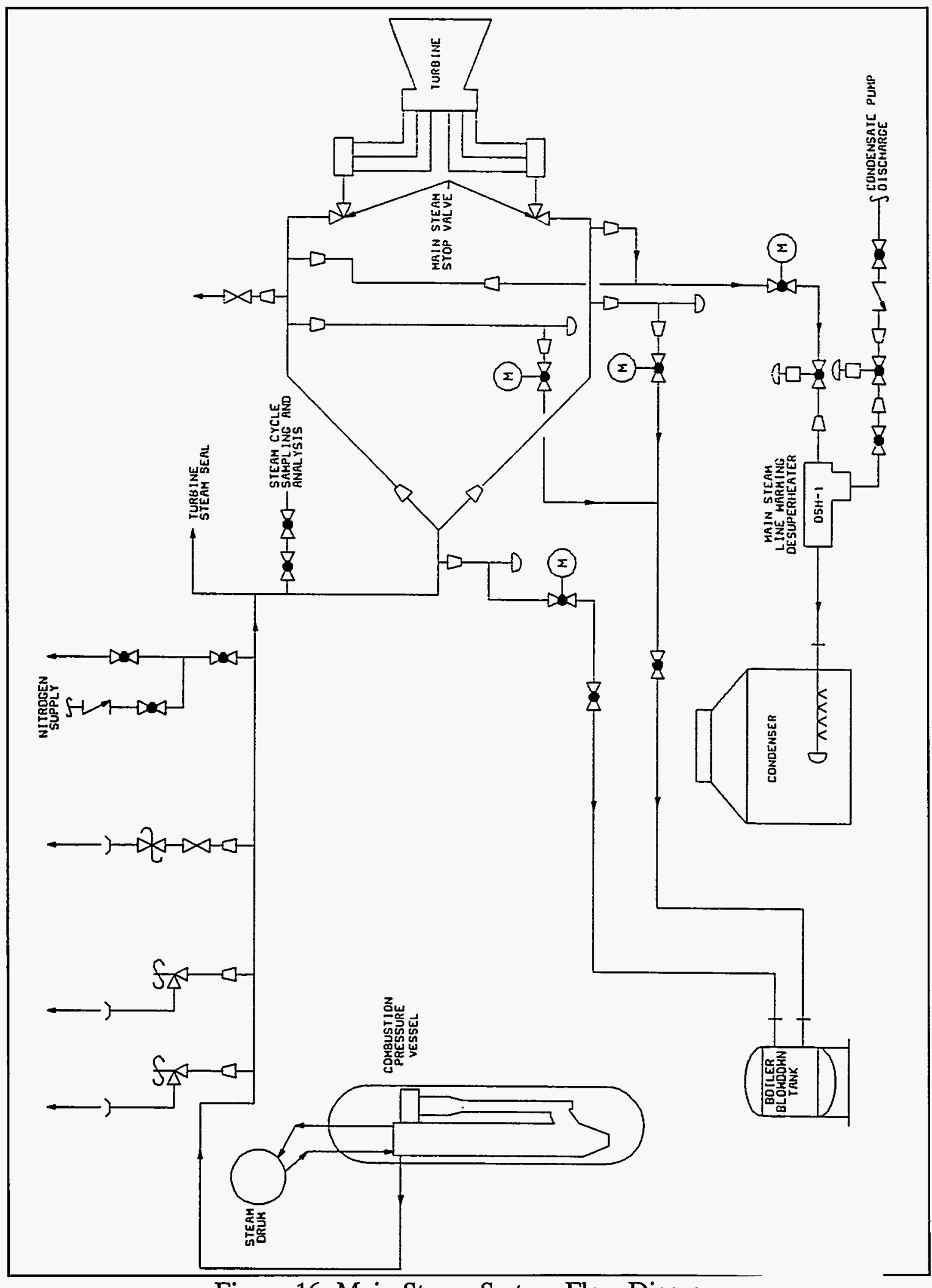

Figure 16: Main Steam System Flow Diagram

051394 
turbine, generator, and exciter.

The existing steam turbine is designed to operate at 3,600 rpm when supplied with steam at $1,250 \mathrm{psig}$ and $950^{\circ} \mathrm{F}$ at the inlet of the steam turbine throttle valves. The steam turbine is manufactured by the Westinghouse Electric Corporation.

The primary steam path through the steam turbine is as follows. Steam flows from the main steam system to two turbine throttle valves which admit high-pressure steam to the steam chest. The turbine governing valves, located within the steam chest, control the flow of steam from the steam chest to the turbine blading and thereby regulate the turbine speed and power output. The steam expands through the high-pressure section of the turbine then enters the low-pressure section via the crossover duct. After passing through the low-pressure stages, the steam flow exhausts downward into the condenser.

During its passage through the turbine, steam is extracted from four stages for feedwater heating, combustion air inlet temperature control, and process steam requirements. Three of the extractions are from Stages 17, 22, and 25 located in the high-pressure section. The fourth extraction is from Stage 28 located in the lowpressure section. Extractions from Stages 17, 22, and 25 supply steam to the two high-pressure feedwater heaters and the deaerator, respectively. The extraction from Stage 28 supplies steam to the low-pressure condensate heater.

An electric motor driven turning gear, mounted between the turbine and the generator, is used prior to steam admission during startup to slowly rotate the turbine. The turning gear is also used following shutdown until the turbine has sufficiently cooled to minimize distortion of the rotor due to uneven cooling of the turbine parts.

Appearance lagging with adequate access doors for in-service inspection and maintenance will enclose the turbine and associated valves and piping located on the operating floor.

The steam turbine will be refurbished to extend its operating life. All valves associated with the turbine will be inspected and refurbished as necessary. Refurbishment of the steam turbine will also include repair or replacement of seals and blades, inspection of bearing journals and blades, and rebuilding of steam throttle valves. A thorough cleaning and flushing of existing lube oil and hydraulic oil heat exchangers, tanks, and associated oil piping will also be completed. 
An existing extraction point from Stage 11 will be capped. The 11th stage extraction point, located in the high-pressure section, supplied steam to a third highpressure feedwater heater which is not required for the repowering project.

\subsubsection{Boiler Feed}

The boiler feed system provides a flow path for feedwater from the deaerator storage tank to the inlet of the HRE located in the gas turbine exhaust stream. The boiler feed system also provides for a portion of the regenerative feedwater heating and provides a flow path for spray water to the superheat attemperators. A simplified process flow diagram of the Boiler Feed System is shown on Figure 17. The system consists of three existing 50 percent capacity, electric motor driven boiler feed pumps, two existing horizontal U-tube type feed water heaters, and a feedwater three-way temperature control valve.

Feedwater for the boiler feed pumps is supplied from the deaerator storage tank. Each of the three boiler feed pumps can provide at least 50 percent of the feedwater required by the boiler. Two pumps must operate to meet the total system flow requirements. Boiler feed pump discharge pressure is sufficient to overcome the friction losses and static head in the high-pressure feedwater heaters and piping and to provide the pressure required at the HRE feedwater inlet connection.

A three-way temperature control valve (TCV) is located in the feedwater piping downstream of the boiler feed pumps. The TCV divides the feedwater stream between a main branch, which passes the feedwater through two high-pressure feedwater heaters in series, and a bypass line. The TCV automatically adjusts feedwater flow to maintain the HRE inlet feedwater temperature set point. This arrangement is required to effectively utilize the capability of existing equipment which is being reused to satisfy the requirements of the new steam cycle.

A branch from the feedwater discharge header supplies water to the two superheat attemperators.

Each feedwater pump is protected against overheating at low flows by a recirculation line and pump recirculation control valve. Boiler feed pump recirculation flow is returned to the deaerator storage tank.

The estimated total boiler feedwater flow is $527,300 \mathrm{lb} / \mathrm{h}$. The design feedwater flow, pressure, and temperature required at the HRE inlet is $516,800 \mathrm{lb} / \mathrm{h}, 1,570 \mathrm{psig}$, and $260^{\circ} \mathrm{F}$, respectively. 


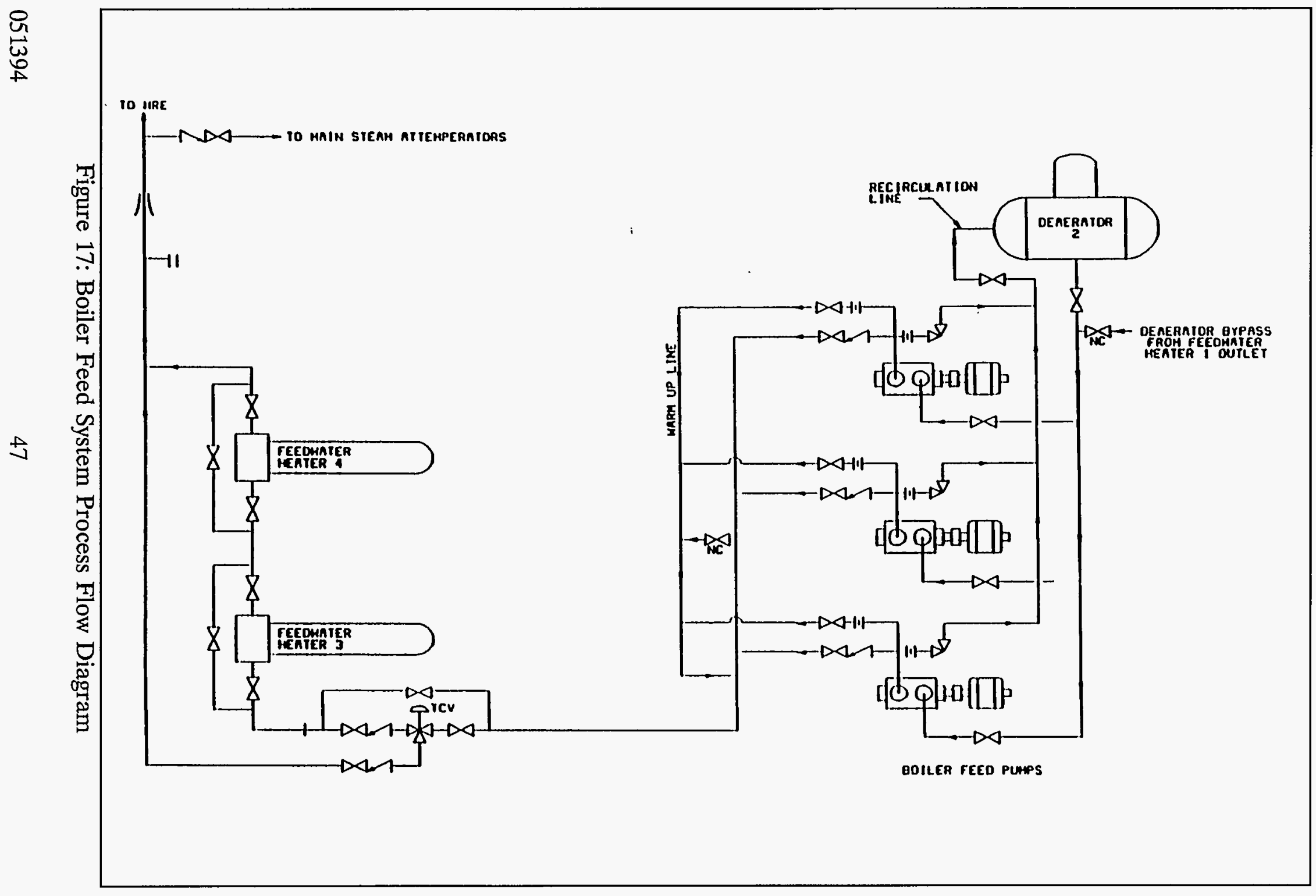


The boiler feedwater design flow rate will be based on the total boiler feedwater required with two pumps in operation while the steam generator is supplying steam at its 2 hour peak rating with the valves wide open. This will include the superheat attemperator spray water, steam generator blowdown, plus a design margin of approximately 5 percent.

The boiler feed pump design head will be the required steam drum inlet pressure plus all friction losses, flow element and control valve losses, and static head losses in both the pump suction and pump discharge lines, plus a design margin of approximately 5 percent.

\subsubsection{Fuel Gas Supply}

The fuel gas supply system provides fuel gas to the PCFB startup burner, the startup combustor, and the auxiliary boiler at the required capacity, pressure, and temperature. Natural gas will be supplied to the fuel gas supply system from the new high-pressure gas header which will be installed on the plant site.

The fuel gas will be supplied to the startup fuel system and the auxiliary boiler at the required temperature, pressure, and flow rate from the high-pressure header. Each pressure regulating station will reduce the incoming gas pressure and maintain a constant gas pressure to the startup burner, the startup combustor, and the auxiliary boiler.

The basket strainers will remove any foreign materials in the fuel gas supply which might damage or interfere with the operation of the startup burners or startup combustors. The gas scrubber will remove moisture and fine particulate from the gas stream. Moisture collected is routed to the gas scrubber drain tank.

The fuel gas supply pressure for the PCFB burner and startup combustor will be 300 psig. Fuel gas supply pressure for the auxiliary boiler will be reduced to the pressure recommended by the auxiliary boiler manufacturer. The flow rate of gas must be sufficient to meet the requirements of the startup burner, the startup combustor, and the auxiliary boiler operating simultaneously.

\subsubsection{Chimney}

The chimney system provides for the discharge of combustion gases to the atmosphere at a sufficiently high elevation to meet air quality limitations and regulations associated with dispersion of pollutants and ground level concentrations. 
The chimney shell will be a reinforced concrete, truncated cone with a varying wall thickness. Openings will be provided in the shell for flue gas entry, personnel access, and gas sampling test probes.

An insulated steel liner will be located within the chimney shell to convey combustion gas to the atmosphere and to protect the shell and equipment in the annulus from high temperatures and corrosive gases.

A chimney foundation will be provided to support the concrete shell and liner. The chimney foundation will be a polygon-shaped reinforced concrete mat supported by piles.

Ductwork through the chimney shell to the liner (chimney breeching) will route flue gas from the heat recovery economizer to the chimney liner.

Platforms will be provided at locations on the chimney as required to provide access to emission monitoring and sampling equipment and test ports and to maintain aviation obstruction lighting. A rack-and-pinion drive, vertical lift service car will be furnished outside the chimney shell for transporting personnel to platforms. A caged ladder equipped with a safety climb device will provide an alternate means of access to the platforms. An electric motor driven hoisting rig located adjacent to the ladder will be provided for lifting equipment.

Continuous emission monitoring equipment and manual compliance sampling ports will be provided at locations on the chimney as required by regulations published by the EPA.

A manually operated rolling steel door will be installed at the base of the chimney shell for equipment access. Hollow metal personnel passage doors will be provided in the chimney shell at ground elevation and at platforms, as required.

Aviation obstruction lighting will be mounted on the chimney shell in accordance with Federal Aviation Administration obstruction marking regulations. The obstruction lighting will be strobes with day and night intensity levels.

A lightning protection system will be provided to protect the chimney structure and associated equipment from damage due to lightning strikes by conducting lightning strike current to the plant grounding system.

The chimney height will be 414 feet based on EPA guidelines for good engineering practice (GEP) and consistent with federal and state regulatory requirements governing ambient air quality. The GEP stack height is a function of the nearby building heights and plan dimensions. 
The majority of the chimney liner will be constructed of unpainted steel which will have extra thickness to provide a corrosion allowance. The top 50 feet of the liner, however, will be constructed of Type 316L stainless steel to provide greater acid resistance. The inside diameter of the liner will be 8 feet 9 inches, based on a maximum flue gas flow of $942,900 \mathrm{lb} / \mathrm{h}$ and a gas velocity of approximately 91 feet per second.

The selection of a steel liner system is based upon the assumption that the dew point for the flue gas will be below $200^{\circ} \mathrm{F}$. Therefore, the formation of acids on the liner is not anticipated under normal operating conditions. It is also assumed that after the demonstration period is completed the unit will be operated as a base load unit and will not be cycled up and down frequently.

\subsection{Electrical Equipment}

\subsubsection{Generator Step-Up Transformer}

The generator step-up transformer system receives power from the steam and gas turbine generators at the $13.8 \mathrm{kV}$ generation level and transforms it to the $161 \mathrm{kV}$ transmission level.

The generator step-up transformer will be one three-winding transformer with two low voltage windings and one high voltage winding. One low voltage winding will be connected to the bus duct from the gas turbine generator breaker, and one low voltage winding will be connected to bus duct from the steam turbine generator breaker. The transformer will be oil-filled with self-cooled and two stages of forced air-cooled ratings. The transformer will be rated for a $65^{\circ} \mathrm{C}$ temperature rise above a $30^{\circ} \mathrm{C}$ average ambient. The generator step-up transformer will be of sufficient capacity to convey to the substation all power generated by the gas and steam turbine generators when the generators are operating at full-capacity and rated power factor of 0.85 .

\subsubsection{Steam Turbine Generator and Excitation}

The steam turbine generator and excitation system converts the mechanical energy of the steam turbine to electrical energy. In addition, the system provides manual and automatic control of the generator terminal voltage and electrical protection of the generator, exciter, generator step-up transformer, and main auxiliary transformer. 
The generator has a rated output of $70,588 \mathrm{kVA}(60,000 \mathrm{~kW}$ at 0.85 power factor) when the hydrogen pressure is maintained at $0.5 \mathrm{psig}$. The nominal terminal voltage of the generator is 14,400 volts at 60 hertz when the generator is operating at the design speed of $3,600 \mathrm{rpm}$.

The new static excitation system includes a potential source static exciter with a base adjuster (manual control) and an ac regulator (automatic control). The new excitation system will be designed by the manufacturer to function with the existing steam turbine generator. The excitation system will also be designed to provide the desired generator operating characteristics and to provide necessary transient operation.

\subsection{System Control}

\subsubsection{Distributed Control and Information System (DCIS)}

The DCIS will be a fully integrated redundant microprocessor-based control, information, and data acquisition system. The DCIS will have a functionally and geographically distributed architecture comprised of a group of similar satellite redundant processing units linked to a group of intelligent visual display work stations by redundant data highways. Each processor will be programmed to perform a specific dedicated task for control, information, and data acquisition applications. Plant equipment motor control functions will be included in the system.

The DCIS will be comprised of two major functional elements: modulating control functions and motor control functions. The modulating control provides for the overall response of the PCFB (with the gas turbine generator) and steam turbine generator in a coordinated mode. The system will provide firing rate control of the PCFB combustion chamber and loading control of the gas turbine control system through a supervisory mode. The system will also transmit load demand signals to the steam turbine digital electrohydraulic (DEH) control system. Additionally, the DCIS will provide control of balance-of-plant equipment through modulating control loops and motor control functions.

The information system, also part of the DCIS, will present information on processes to the operator in the Control Room. The information functions include information displaying, printing of logs, historical data storage and retrieval, calculations, and annunciation functions. The information will be displayed through cathode ray tube (CRT) stations located on the main control console in the form of bar 
charts, process mimics (graphics), lists of parameter values, alarm windows, etc. Computer data logging operations will provide for automatic record keeping and generation of plant logs by log printers. Scanned out-of-limit parameters and digital alarms will be displayed on CRTs and recorded on a dedicated alarm printer. A sequence-of-events recorder (SOE) function will be provided for alarms which indicate the cause of a unit trip, major equipment trip, or protective system trip. The SOE alarms will appear in sequence to a resolution of 1 millisecond, both on a designated CRT and printer.

\subsubsection{Steam Turbine Controls and Instrumentation}

The steam turbine control and instrumentation system senses and computes pertinent steam turbine generator operational information for use by plant operators and control systems. It provides a means for control of the steam turbine operation during preroll and acceleration and over the full operational range. It also provides protection to the steam turbine against potentially dangerous operating conditions.

The steam turbine control and instrumentation system consists of a unique set of subsystems required for steam turbine control and supervision. When packaged together and interfaced with the Distributed Control and Information System (DCIS), these subsystems as a group perform all required control/information functions for the steam turbine and can be categorized as follows:

- Turbine governing/protective subsystem.

- Turbine generator supervisory instrument subsystem.

- Sequence logic subsystem.

The turbine governing/protective subsystem will incorporate a DEH system for control of turbine speed, acceleration, and load over the entire turbine operating range. The DEH system will include a high-pressure hydraulic power unit complete with the necessary pumps, valves, dual coolers, piping, fluid reservoir, and associated control and instrument equipment. The turbine governing/protective subsystem will also provide necessary protection of the steam turbine against potentially damaging conditions. The turbine controls will also provide for the execution of automatic tripping actions as commanded by the unit protection system, and protect the steam turbine against occurrence of abnormal operating conditions, including the following:

- High vibrational levels.

- Overspeed.

- High thrust bearing wear. 
- Low vacuum.

- Low lube oil pressure.

- Low hydraulic fluid pressure.

- Other abnormal operating conditions involving turbine auxiliary systems such as lube oil, cooling, startup fuel system, and generator protective systems.

The turbine generator supervisory instrument subsystem includes devices to sense and indicate parameters necessary to monitor the operation of the steam turbine generator. The steam turbine generator supervisory instrument subsystem includes alarms to notify the operator when these parameters approach limits or exceed tolerance. The data from the instrumentation is made available to the DCIS for operator use, display, and recording.

The sequence logic subsystem provides the sequencing required for startup, normal shutdown, and emergency shutdown procedures. It includes checks during a startup sequence to ensure that auxiliary equipment is operating properly before proceeding to the next step.

\subsubsection{Automatic Generation Control}

The load control system establishes the generation level required for the unit based on load commands from the Midwest Power's Remote Dispatch Center and transmits load increase or decrease commands to the DCIS to satisfy the required demand.

An interface between Midwest Power's Remote Dispatch Center and the DCIS will provide the mechanism for load control of the unit. Two contact closure signals will be provided from the remote dispatch center for generation "raise" and "lower" signals. The DCIS will transmit unit status information back to the remote dispatch center.

\subsubsection{Fuel Burning Control System}

The fuel burning control system provides protection for the steam generator and the associated equipment. The fuel burning control system monitors conditions of the steam generator and the associated equipment to detect any hazardous condition and initiates the appropriate protective action. The fuel burning control system controls the sequence of operations during startup and shutdown to ensure safe operation of the steam generator. The system provides remote safe light-off and shutdown of the startup burners and fuel delivery equipment from the control room. 
The fuel burning control system uses redundant processors and will interface with the plant DCIS via the DCIS redundant data highways except that critical inputs and outputs of the fuel burning control system will be hard-wired to the DCIS unit protection system to ensure safe shutdown sequences of the PCFB. Redundant data links are provided with the fuel burning control system for interface with the DCIS.

Prior to light-off, the logic of the fuel burning control system will enforce proper purging of the PCFB. Once purge is complete, startup burner light-off will be permitted. After the process parameters of the pressure vessel are at the required levels and the appropriate permissives are satisfied, solid fuel is permitted to flow into the PCFB.

During normal operation, the fuel burning control system monitors required pressures, temperatures, fuel flow, airflow, and the necessary fuel delivery aid firing equipment associated with the PCFB. The fuel burning control system will initiate appropriate protective action and necessary shutdown sequences if an unsatisfactory condition develops or if commanded to do so by the unit protection system. The fuel burning control system will include all logic required for tripping the unit trip relay system which is part of the unit protection system on critical conditions under the fuel burning control system's management.

\subsubsection{Unit Protection}

The unit protection system will monitor the operating status of the PCFB, the steam turbine generator, the gas turbine and critical cycle process parameters and will initiate an automatic shutdown of the entire unit if required by hazardous operating conditions. The Unit Protection System includes a unit overall trip system and steam turbine water induction protection system. The unit overall trip system includes a 2-out-of-3 system for sensing and a 1-out-of-2 energize-to-trip configuration for providing trip outputs to equipment.

The 2-out-of-3 sensing system will be implemented through redundant functional processors of the DCIS. In the 2-out-of-3 sensing system, when a measured parameter exceeds its set point, logic is triggered to initiate a unit trip. Protective action occurs when at least two of the three sensing devices indicate a unit trip is required. The 2-out-of-3 sensing ensures that a failure in one of the sensing channels will not cause a misoperation of the system. This design also allows the field sensors and tripping devices to be tested individually without inhibiting any protection capabilities. All 2-out-of-3 logic will be implemented in both functional processors of a 
redundant pair. Operation of the 2-out-of-3 logic (through outputs of the redundant functional processors) causes the trip coils in the two identical dc energize-to-trip unit trip relays to become energized, in turn opening or closing associated contacts which are the trip signal devices for the interfacing systems. The unit trip relays are arranged in a 1-out-of-2 energize-to-trip configuration so that failure of one coil to operate does not prevent a trip. Certain parameters bypass the 2-out-of-3 logic and operate the 1-out-of- $2 \mathrm{dc}$ unit trip relays directly. These are parameters which do not require field sensors to measure a process variable.

The two 1-out-of- 2 dc energize-to-trip unit trip relays are electrically resettable lockout relays and will remain in the trip state until they are reset by means of an operator reset push button. However, the reset cannot be accomplished until all trip inputs have returned to their normal condition. The reset is operator initiated.

When either or both of the unit trip relays initiate a unit trip, the unit trip system sends signals to the fuel burning control system and the steam turbine controls. Each unit trip relay provides a complete set of trip outputs.

Also included in the unit overall trip system will be the control and indicator subpanel to facilitate the mounting of all push buttons and indicating lights associated with the system. The subpanel will be located on the main control console.

Sequence-of-events annunciation through the DCIS will be provided to alarm abnormal conditions detected, protective actions initiated, and protective system component failures.

The steam turbine water induction protection system will sense the abnormal operating conditions where the possibility of water introduction into the steam turbine exists and will initiate the actions to dispose of the water accumulations or isolate the turbine from this potential source of water. This system will monitor instrumentation sensing water accumulations within steam line drainlines, will actuate process control and shutoff valves, and will generate alarms as required.

The unit protection system will be designed to minimize the probability of initiating an unnecessary trip or of preventing a valid trip. A failure of any single protection system component will not cause a false trip nor inhibit a valid trip. It will also be designed to minimize the expenditure of fatigue life of the equipment during the unit trips and to include provisions for testing of components without degrading the system by loss of protection or unnecessary tripping.

The unit protection system will be independent of operator action, except that the operator can initiate a trip. The operator cannot inhibit a trip. 
The steam turbine water induction protection system shall be designed so that no single failure of equipment can in itself be a cause of water entering the turbine. The failure mode of the various devices used to prevent water induction shall be considered such that a single failure of the signals (loss of air or electrical signal) will not allow water to enter the turbine.

\subsection{Cooling Systems}

\subsubsection{Auxiliary Cooling Water}

The auxiliary cooling water system transfers heat rejected by various plant equipment heat exchangers to the circulating water system. Two new full-capacity auxiliary cooling water pumps will be installed in the existing circulating water tunnel pit. The auxiliary cooling water pumps will supply auxiliary cooling water to various plant heat exchangers through a common header, and will discharge the auxiliary cooling water into the existing 60 inch circulating water return header to the cooling tower. A side stream, passing through the chemical feed and chlorination branch, will be returned to the tunnel pit.

Normally, individual users of auxiliary cooling water will be manually controlled by a balancing valve in the heat exchanger discharge piping. The auxiliary cooling water system will be designed on the basis of constant flow. Any system requiring a modulated flow for temperature control shall include a bypass system to maintain constant flow in the auxiliary cooling water system.

The auxiliary cooling water heat exchangers will be designed to provide closed cycle cooling water at a temperature not exceeding $105^{\circ} \mathrm{F}$ during unit operation at maximum load with circulating water at $90^{\circ} \mathrm{F}$.

\subsubsection{Closed Cycle Cooling Water}

The closed cycle cooling water system transfers heat rejected by the various plant equipment heat exchangers to the auxiliary cooling water system.

The closed cycle cooling water system will supply condensate quality cooling water to plant equipment heat exchangers. The auxiliary cooling water heat exchangers, which are included in the auxiliary cooling water system, will transfer heat from the closed cycle cooling water to the auxiliary cooling water. Two fullcapacity pumps will circulate the closed cycle cooling water through the auxiliary cooling water heat exchangers and the various plant equipment heat exchangers. An elevated closed cycle cooling water tank will provide surge capability, a location for 
system makeup and venting, and static head. To minimize corrosion, a corrosion inhibiting chemical solution will be added to the closed cycle cooling water system through a pot feeder.

The various plant equipment heat exchangers, except for air compressor intercoolers and aftercoolers, will receive cooling water from a common supply header. The plant equipment heat exchangers will discharge the heated closed cycle cooling water to a common discharge header. The cooling water temperature in the common supply header is controlled by bypassing the auxiliary cooling water heat exchangers with a portion of the heated return water flow.

Normally, individual heat exchanger flow will be manually controlled by a balancing valve in the heat exchanger discharge piping. The exceptions will be any equipment requiring more precise temperature control. The exceptions will have temperature sensing and controlling devices included as part of their respective systems to provide the input to cooling water flow control valves.

The air compressor intercoolers and aftercoolers receive cooling water directly from the auxiliary heat exchanger outlet. This supply source, taken before the bypass temperature mixing, provides the coldest water possible to these coolers to obtain highest efficiency. The air compressor cooling water is returned to the closed cycle cooling water tank to allow for air venting if air-to-water side cooler leakage occurs. For initial operation of the air compressors before auxiliary cooling water and closed cycle cooling water are available, service water will be used as the cooling medium. The service water will be supplied through temporary valved connections on the inlets and outlets of the air compressor coolers.

A control valve will be provided to maintain the differential pressure between the closed cycle cooling water supply and return headers at a value greater than the maximum differential pressure across any plant equipment heat exchanger. This will ensure adequate cooling water flow to all coolers and equipment on the closed cooling cycle. The circulating water inlet temperature to the auxiliary cooling water heat exchanger will be $90^{\circ} \mathrm{F}$. The auxiliary cooling water flow rate will be determined by the total of all the plant heat exchanger flow requirements.

The two 100 percent capacity closed cycle cooling water pumps will be of the horizontal split case, single stage, double-suction, volute type with mechanical seals. The closed cycle cooling water pumps will be designed with sufficient pumping capacity and total developed head to circulate closed cycle cooling water through the Closed Cycle Cooling System. The pumps will be driven by electric motors. 
The existing closed cycle cooling water tank (bearing cooling head tank) is of the vertical cylindrical, convex head, bottom supported type. The existing tank will be thoroughly inspected and modified and/or repaired as required to function as the head tank for the new closed cycle cooling water system.

\subsubsection{Condensate System}

The condensate system provides a flow path for water from the condenser hot well to the deaerator, and raises the temperature of the condensate through regenerative feedwater heating. The condensate then circulates through the hydrogen coolers, hydrogen seal oil cooler, one of two turbine lube oil coolers, and provides condensate makeup to the closed cycle cooling water head tank. The condensate system also supplies injection water to the boiler feed pump seals, and spray water to the main steam warming desuperheaters.

The condensate system consists of the following major components:

- One existing horizontal, U-tube type, low-pressure feedwater heater.

- Two existing condensate surge/storage tanks each with a capacity of 45,000 gallons.

- One existing modified direct-contact, tray type deaerator with a horizontal cylindrical shell storage tank, and two existing top mounted horizontal vent condensers.

- Two new 100 percent capacity electric motor driven condensate pumps.

- Five existing pneumatic operated condensate flow regulating valves, with the operators and positioners replaced as required to interface with a new DCIS

Two 100 percent capacity condensate pumps take suction from the condenser hot well. The discharge pressure of the condensate pumps is sufficient to overcome the friction losses in the condensate system piping and valves, low-pressure Feedwater Heater 1, condensate cooler, hydrogen coolers, hydrogen seal oil cooler, turbine lube oil cooler, flow measuring orifices, and to overcome system static head.

The condensate pumps discharge feedwater to either the inlet of a condensate cooler or directly to the hydrogen coolers and hydrogen seal oil cooler. The condensate cooler is used when the condenser hot well temperature is greater than $95^{\circ} \mathrm{F}$. The bypass around the hydrogen coolers includes a temperature control valve which maintains the hydrogen cooler outlet condensate temperature at a set point of $104^{\circ} \mathrm{F}$. Condensate downstream of the hydrogen coolers and bypass line is directed to the turbine lube oil cooler. Condensate flow paths join downstream of the turbine 
lube oil cooler and hydrogen seal oil cooler into a single condensate flow stream which passes through a condensate flow controller, low-pressure Feedwater Heater 1, and is discharged to the deaerator or surge tanks based on the level in the deaerator storage tank section. At reduced loads, a portion of the condensate recirculates to the condenser to provide the minimum condensate flow required for the hydrogen coolers, turbine lube oil and hydrogen seal oil cooler. The deaerator is of the directcontact tray type which discharges deaerated condensate downward into an internal, horizontal, cylindrical storage tank section. The deaerator will be refurbished, or if required, modified (trays added or replaced) to limit the residual oxygen/condensate concentration to $0.005 \mathrm{cc}$ per liter for unit loads between 5 percent of rated and rated, inclusive. 


\subsection{Site}

Description of the site includes building and structures, roads, and rail access. A general site arrangement can be found on Figure 18.

\subsection{Buildings and Structures}

\subsubsection{Steam Generator Building}

The steam generator building provides support, enclosure, protection, and access to the systems included within its boundaries.

5.1.1.1 Description. The steam generator building will house the following equipment and materials:

- Steam generator (PCFB boiler).

- Ceramic filters.

- Bed ash handling system.

- Filter ash handling system.

- Limestone silo and feeder equipment.

- Sand silo and feeder equipment.

- Auxiliary systems.

- Compressors.

- Flue gas and combustion air ductwork.

- Fuel feed equipment and piping.

- Elevator.

The steam generator building will be constructed on the site of the old boiler 10 building. The existing boiler 10 superstructure will be demolished prior to the construction of the new steam generator building. The boiler 10 building foundation is still in place. In accordance with Midwest Power's request, a study will be conducted to determine the extent to which the existing foundation might be reused. Options to be considered include the following:

- Reuse the existing piles and pile caps by placing new columns directly on the old pile caps. New piles and pile caps would be placed between the existing pile caps as needed.

- Reuse the existing piles and pile caps by placing a new mat over the old pile caps. New piles would be driven between the existing pile caps as needed prior to placing the new mat. 


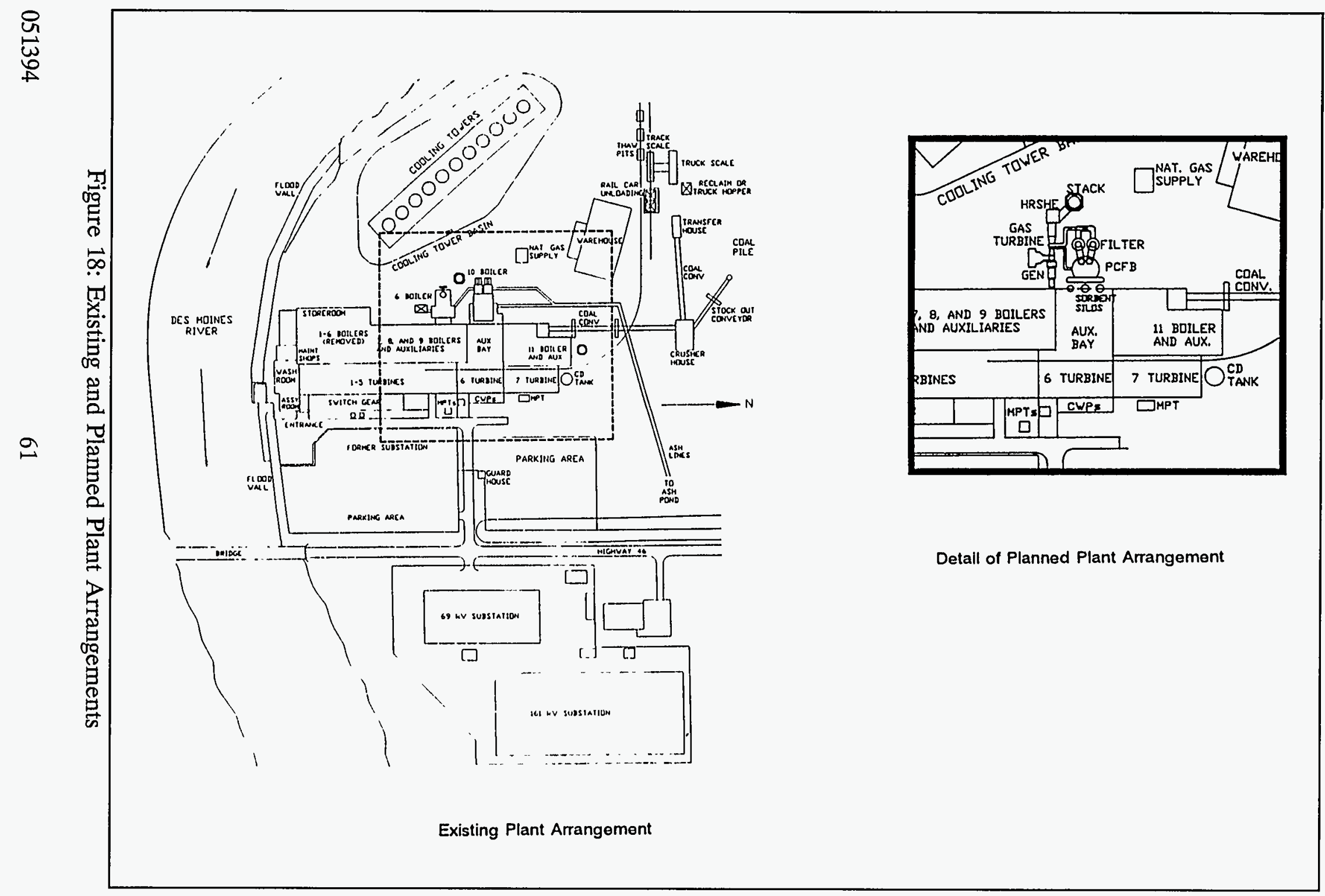


- Demolish the existing pile caps and slabs so that only the existing piles remain. Install new extra piles as needed. Place new pile caps or a new concrete mat over the piles.

The steam generator building foundation will provide support for the superstructure and ground floor equipment and will provide access and work space. The foundation will be either a concrete mat on piles or a system of piles, pile caps, grade beams, and a slab.

The steam generator building structural steel frame will be a structural system composed of simply supported interconnected members and a horizontal and vertical bracing system to transmit wind, seismic, and other lateral forces to the foundation.

The steam generator pressure vessel will be bottom supported prior to and during hydrotesting. After hydrotesting is completed, the Pressure Vessel Support System will be converted to a top supported system.

5.1.1.2 Design Requirements. The steam generator building will be designed to safely support the applied loads.

An existing circulating water tunnel passes underneath the steam generator building. Foundations for the new building will be designed to accommodate the presence of this tunnel.

General personnel access to equipment will be provided through the use of stairs, an elevator, floors, and platforms. Crane or hoist systems will be provided to access the following equipment:

- Pressure vessel components.

- Ceramic filters.

- Filter ash coolers.

- Bed ash coolers.

A vertical lifting area will be provided for the full height of the steam generator building to allow for access and maintenance. A hoist will be provided at the top of the vertical lifting area.

The steam generator building will be totally enclosed. Exterior walls for the building will consist of insulated metal wall panel with a precast concrete basewall. The roof will be a single-ply membrane over insulation and metal roof deck. A steel trawled surface hardened concrete finish will be provided for the ground floor. Floors and platforms above grade will be a mix of grating and suspended concrete slabs.

Wastewater subject to oil contamination will be treated in an oil/water separator. 
The hot drain system will be kept separate from other drainage systems until it reaches the first wet manhole outside of the building. This will prevent steam from rising through other drain pipes.

\subsubsection{Turbine Generator Building/Auxiliary Bay}

The existing turbine generator building provides support, enclosure, protection, and access to the systems included within its boundaries. (The auxiliary bay will be considered as part of the turbine generator building for this write-up.)

5.1.2.1 Description. The existing turbine generator building will undergo structural modifications as required to accommodate the new equipment arrangement. The turbine generator building will house the following equipment and materials:

- Turbine generator.

- Condenser.

- Control console, control equipment, and control facilities.

- Feedwater heaters and deaerator.

- Condensate pumps.

- Turbine lube oil and electrohydraulic control equipment.

- Generator lead bus duct.

- Steam turbine generator breaker.

- Medium voltage switchgear.

- Motor Control Centers.

- Secondary Unit Substation.

- Main steam piping.

- Boiler feed pumps.

- Turbine laydown and maintenance.

- Turbine room crane.

- Coal bunkers.

- Coal crushers.

- Primary and secondary mixers.

- Paste pumps.

- Demineralizer equipment.

- Cycle chemical feed.

- Battery and invertor equipment.

- Electrical equipment room.

- Auxiliary cooling water heat exchangers. 
- Auxiliary cooling water pumps.

- Air compressors.

- Air receivers.

The existing turbine generator building foundation provides support for the superstructure and the turbine pedestal and provides a working surface at ground floor level. The turbine foundation and pedestal, which extends between ground floor and the operating level, supports the turbine generator and condenser.

The turbine generator building structural steel frame is a structural system composed of simply supported interconnected members and a horizontal and vertical bracing system for lateral support.

The turbine generator building is totally enclosed. The exterior walls are constructed of brick masonry. The roof is a conventional built-up roof.

Maintenance access in the existing turbine generator building consists of a large rolling steel door adjacent to the turbine access hatch which runs between the ground and operating floor levels. A turbine room bridge crane is available for turbine and auxiliary equipment erection and maintenance. The crane travels above the operating floor level, the entire length and width of the area. The operating floor has removable access covers over the condensate pumps, turbine oil cooler, and main steam throttle valves. Space allocation will permit condenser and heat exchanger tube pulls and allow for turbine laydown and rotor removal area.

The turbine generator building will house the control center area. The control center area will provide an environmentally controlled area for the following equipment and rooms:

- Office space.

- Main plant control room and associated areas.

- Control equipment.

- Battery room.

This area will be pressurized, with the temperature and humidity controlled by HVAC equipment. The control instruments, cabinets, and devices require a clean and moderate climate controlled environment.

5.1.2.2 Design Requirements. The following structural modifications will be required for this building:

- Add support steel and access platforms for the secondary mixers.

- Add a suspended slab to support and access the primary mixers. 
- Add a suspended slab to support and access the coal crushers and drives.

- Add a hoist/monorail system to access the coal crushers and drives.

- Provide miscellaneous steel as needed to accommodate the new equipment and arrangement.

The turbine generator building modifications will be designed to safely support the applied loads.

The existing roof system currently has leakage problems. At some point early in the project the existing roof will need to be replaced. The existing built-up roof will be removed down to the metal deck and replaced with a new roof composed of a single-ply membrane over insulation. The roof drain system has likely been damaged as well and will also require repairs.

General personnel access to equipment will be provided through the use of stairs, an elevator, floors, and platforms. A hoist system will be provided to access the coal crushers and their drives.

Wastewater subject to oil contamination will be treated in an oil/water separator. The hot drain system will be kept separate from other drainage systems until it reaches the first wet manhole outside of the building. This will prevent steam from rising through their drain pipes. Chemical drains will be routed to a neutralization basin for treatment.

\subsubsection{Gas Turbine Building}

The gas turbine building provides support, enclosure, protection, and access to the systems included within its boundaries.

5.1.3.1 Description. The gas turbine building will house the following equipment and materials:

- Gas turbine

- Gas turbine generator.

- Gas turbine aftercooler.

- Inlet air temperature controller.

- Inlet heater skid.

- Turbine lube oil cooler.

- Turbine laydown and maintenance.

- Turbine room crane.

- Fuel oil skid.

- Fuel/gas water injection skid. 
- Control skid.

- Switchgear.

- Startup package.

- Gas turbine generator breaker.

- Generator bus duct.

The gas turbine building will be constructed on the site of the old high-pressure boiler No. 6 building. The existing high-pressure boiler No. 6 superstructure has already been demolished, however; the foundation still remains in place. In accordance with Midwest Power's request, a study will be conducted to determine the extent to which the existing foundation might be reused. Options to be considered include the following:

- Reuse the existing piles and pile caps by placing new columns directly on the old pile caps. New piles and pile caps would be placed between the existing pile caps as needed.

- Reuse the existing piles and pile caps by placing a new mat over the old pile caps. New piles would be driven between the existing pile caps as needed prior to placing the new mat.

- Demolish the existing pile caps and slabs so that only the existing piles remain. Install new extra piles as needed. Place new pile caps or a new concrete mat over the piles.

The gas turbine building foundation will provide support for the superstructure and ground floor equipment as well as providing access and work space for the ground floor level. The foundation will be either a concrete mat on piles or a system of piles, pile caps, grade beams, and a slab.

The gas turbine building structural steel frame is a structural system composed of simply supported interconnected members and a horizontal and vertical bracing system designed to transmit wind and other lateral forces to the foundation.

5.1.3.2 Design Requirements. A bridge crane will be installed to provide access to the gas turbine and the generator. The longitudinal axis of the gas turbine will lie in the east/west direction.

The gas turbine building will be totally enclosed. Exterior walls for the building will consist of insulated metal wall panel with a precast concrete base wall. The roof will be a single-ply membrane over insulation and metal roof deck. Steel trawled surface hardened concrete will be used for the ground floor. 


\subsubsection{Administration/Plant Services Building (Existing Turbine Hall and Boiler Building)}

The administration/plant services building provides support, enclosure, protection, and access to the systems included within its boundaries.

5.1.4.1 Description. The administration/plant services building will be located in renovated sections of the existing turbine hall and boiler building which are located south of the turbine 6/boiler 10 unit. The existing turbine hall, which housed turbines 1 through 5, will be renovated into office space and locker facilities. The existing boiler building, which housed boilers 1 through 9, will be renovated to accommodate its new function as a shop and storage area.

Portions of the 1925 turbine hall, boiler building, and switch house along with the existing training room and cafeteria will be demolished to accommodate the new facilities. The portions of the old structure to be demolished are generally located south of a line which is located 4'-0" south of column row 195 (224 feet south of Column Row 209). A new south wall will be constructed at this location and will contain the main entrance. The new south wall will be constructed of masonry which has been salvaged from the demolished portions of the building.

the new administration/plant services building will provide areas for the following support facilities:

- Plant administrative offices (14 offices).

- Meeting room.

- Lunch room

- Two conference rooms.

- Visitor's space.

- Water/coal analysis lab.

- Drawing room.

- Locker room facilities.

- Machine shop.

- Electrical shop.

- Instrument shop.

- Storage areas.

The total floor area for the administration portion of the building will be approximately 32,000 square feet. The total floor area for the plant services portion of the building will be approximately 17,300 square feet. 
The existing turbine/boiler buildings are braced frame steel structures. The buildings were first constructed in 1925 with additions occurring in 1938 and 1949.

The existing turbine/boiler buildings are totally enclosed structures with walls of brick masonry.

5.1.4.2 Design Criteria. The administration/plant services building structural modifications will be designed to safely support the applied loads.

The existing roof system currently has leakage problems. At some point early in the project, the existing roof will need to be replaced. The existing built-up roof will be removed down to the deck and replaced with a new roof composed of a single-ply membrane over insulation. The roof drain system has likely been damaged as well and will also require repairs.

Sanitary wastewater will remain entirely isolated from other wastewaters. Sanitary wastewater drains will be discharged directly to the Des Moines city sewer system. There will be no onsite treatment of sanitary wastes.

Wastewater subject to oil contamination will be treated in an oil/water separator. The hot drain system will be kept separate from other drainage systems until it reaches the first wet manhole outside of the building. This will prevent steam from rising through other drain pipes. Chemical drains will be routed to a neutralization basin for treatment.

\subsubsection{Coal Transfer Building (Existing Coal Crusher House)}

The coal transfer building provides structural support, enclosure, protection, and access to the systems contained within its boundaries.

5.1.5.1 Description. The coal transfer building will contain the following equipment and materials:

- New sample system (located adjacent to Coal Transfer Building).

- Existing coal crusher (To be abandoned).

- Existing conveyor transfer point.

- Existing fire protection equipment.

- Switchgear.

The coal transfer building is a structural steel braced frame building. The structure is totally enclosed by metal wall and roof panels. Access is provided by exterior doors and a stair tower.

5.1.5.2 Design Requirements. The coal transfer building provides support for the existing coal crusher and crusher feeder. However, this existing crusher system 
will be abandoned. (Two new replacement crushers will be housed in the auxiliary bay adjacent to the turbine 6 building.) The existing coal transfer building will be modified and reused as a transfer point only.

A new coal sampling system will be installed just west of the coal transfer building. An evaluation will be made during detailed design to determine whether the sampling equipment should be housed in a new separate building, housed in an extension of the existing coal transfer building, or purchased with its own enclosure structure. The new sampling equipment cannot be housed within the existing coal transfer building because there is insufficient space available for the new swing arm type sampling system. The existing conveyor belt take-up system would also interfere with the sampling equipment. Also the sampling system needs to be located a sufficient distance from the head pulley to ensure that a normal belt cross-sectional shape exists.

The coal transfer building modifications will be designed to safely support the applied loads.

New exterior walls required for the sample system enclosure will be uninsulated metal wall panels. The roof over the new sampling area will also be constructed of uninsulated metal panels.

\subsubsection{Gas Meter House}

The gas meter house provides support, enclosure, protection, and access to the systems included within its boundaries.

5.1.6.1 Description. The gas meter house will contain the following equipment and materials:

- Gas meter.

- Gas regulator.

- Gas scrubbing equipment.

A small building is expected to be provided by the gas company to house the gas meter, however, it is doubtful that this building will be large enough to house the gas regulator and the gas scrubbing equipment. Therefore, either an additional building will be required, or else an agreement will need to be reached with the gas company to enlarge their building and to have Midwest Power share in the extra cost.

The gas meter house foundation will provide support for the superstructure and ground floor equipment as well as providing access and work space. The foundation will consist of spread footings, grade beams, and a slab. 
The gas meter house will be a single story pre-engineered metal building with a gabled roof.

5.1.6.2 Design Requirements. The gas meter house will be totally enclosed. Exterior walls for the building will consist of insulated metal wall panels. The roof will be an insulated metal standing seam roof. Steel trawled surface hardened concrete will be used for the floor slab.

\subsubsection{Warehouse}

The warehouse will provide enclosure, protection, and access for the storage of station equipment.

5.1.7.1 Description. A new warehouse will be provided to replace the existing warehouse. The new warehouse foundation will provide support for the superstructure and ground floor equipment and will provide access and work space. The foundation will consist of spread footings, grade beams, and a slab.

The new warehouse will be a single story pre-engineered metal building with a gabled roof. The building will be approximately 75 feet wide by 100 feet long with an eave height of approximately 18 feet. The building will be a clearspan rigid frame structure with no interior columns.

General personnel access to equipment will be provided through the use of exterior doors and adequate space around the equipment. An underhung bridge crane will be installed to provide access to the stored equipment.

Exterior walls for the building will consist of insulated metal wall panels. The roof will be an insulated standing seam metal roof. The concrete floor will have a steel trawled surface hardened finish.

\subsubsection{Circulating Water Chemical Feed Building}

The circulating water chemical feed building provides support, enclosure, protection, and access to the systems included within its boundaries.

5.1.8.1 Description. The circulating water chemical feed building will house the following equipment and materials:

- Chlorination equipment.

- Scale inhibitor feed equipment.

The circulating water chemical feed building foundation will provide support for the superstructure and equipment and will provide access and work space. It is 
anticipated that the circulating water chemical feed building will house four 1 ton chlorine cylinders. The foundation will consist of a system of spread footings, grade beams, and a slab.

The circulating water chemical feed building will be a single story pre-engineered metal building with a gabled roof. The building size will be approximately 15 feet wide by 20 feet long with an eave height of about 14 feet. The building will be totally enclosed. The exterior walls will consist of insulated metal wall panels. The roof will be an insulated metal standing seam roof.

General personnel access to equipment will be provided through the use of exterior doors and adequate space around the equipment. Two steel trunions will be provided to support each chlorine cylinder. The trunions will be expansion anchored to the floor. A monorail and hoist will be provided in the building for accessing the chlorine cylinders.

The chlorine cylinders will be stored inside the building. A concrete pad will be provided outside of the building to facilitate handling of the chlorine cylinders.

5.1.8.2 Design requirements. The circulating water chemical feed building will be designed to safely support the applied loads and to ultimately transmit these loads to the underlying soil.

Exterior walls for the building will consist of insulated metal wall panels. The roof will be an insulated standing seam metal roof. Steel trawled surface hardened concrete will be used for the ground floor.

Floor drains will be provided for washdown water.

\subsection{Site Access}

The site will be accessible by roads for personnel, coal deliveries, and waste disposal. The site will be accessible by rail for major equipment delivery and coal deliveries.

\subsubsection{Roads and Parking}

The roads and parking system provides vehicular access from existing State Highway 46 to all primary yard structures and major activity areas during construction and commercial operation.

5.2.1.1 Major Components. The roads and parking system will consist of the following major components:

- Main plant access roads. 
- Secondary access roads.

- Permanent parking.

5.2.1.2 Description. Primary access to the plant site during normal plant operation will be provided by Highway 46 . Highway 46 runs through the site to the east of the main plant complex, turns west, and then borders the site on the north. The main entrance to the plant is near the Highway 46 crossing of the Des Moines River. Additional roads will be provided around the central plant complex area, around the coal storage area, and to access all primary yard structures. A new ash haul road will be provided to the ash disposal area to the east of Highway 46 .

The main plant access road and the main plant complex circumferential road will be asphalt paved. Secondary access roads will be surfaced with aggregate, except for the access road to the new warehouse. This will be asphalt paved. General area paving will be provided in delivery and loading areas adjacent to the plant circumferential road. Paving will be deferred until major construction activities are completed.

A permanent paved parking area will be provided for visitors and administrative personnel south of the administration/plant services building. This parking area will provide space for 30 vehicles, including two handicapped stalls. Fifteen stalls will be provided on the north side of the parking area. The parking area on the south side of the aisle will provide 15 more car/pickup stalls or space for visitors' vans or busses. The current paved parking area near the main entrance and guard house will be repaved and will provide parking for the operation and maintenance staff. A minimum of 20 stalls will be provided, including two handicapped stalls. Secondary aggregate surfaced parking areas will be provided at the coal handling structures, cooling tower area, and other miscellaneous plant structures.

5.2.1.3 Design Requirements. The roads and parking system will be designed to provide access to the site and to all site structures, and to provide parking for plant personnel and visitors.

\subsubsection{Railroads}

The railroads system provides onsite trackage to facilitate coal delivery and transportation of materials and equipment for construction and maintenance.

5.2.2.1 Major Components. The railroads system will consist of the following major components:

- Rails and other truck material. 
- Cross-ties and switch ties.

- Ballast.

- Crossing and turnouts.

5.2.2.2 Description. The plant is currently served by a spur line of the $\mathrm{BN}$ Railroad. This spur is connected to the BN main line at Albia, Iowa, through trackage rights over Norfolk Southern Railroad between Albia and Des Moines. The spur was capable of handling 100 ton equipment when the Des Moines Energy Center was in operation, but will need to be upgraded to FRA Class 2 condition as a minimum before service is resumed. On the curves, FRA Class 3 is preferred as it provides the needed increase in track strength. Adjacent industries on the spur continue to receive rail service, and it is anticipated that only the onsite trackage will need upgrading. Connections can also be made from the C\&NW line at Nevada, Iowa, south to the BN yard in Des Moines.

Midwest Power will not receive frozen coal at the plant. Therefore, a thaw shed will not be needed. They will divert trains hauling frozen coal, which are equipped to handle frozen coal, to other plants in the Midwest Power System. Only upgrading of existing track is planned, and some existing track will be removed to accommodate new construction.

5. 2. 2.3 Design Requirements. The Railroad System will be designed to provide rail delivery of coal by a unit train. An entire unit train is not able to enter the railyards northwest of the plant. Therefore, the cars will be switched in 45-50 car cuts to the site rail loop. Improvements to the track work will be in accordance with FRA Class 2 with FRA Class 3 required on the curves. 


\subsection{Environmental Provisions}

\subsection{Combustion Gases Sampling and Analysis}

The Combustion Gases Sampling and Analysis System will sample and analyze combustion gases of the pressurized circulating fluidized bedboiler for $\mathrm{NO}_{\mathrm{x}}, \mathrm{CO}_{2}$, or $\mathrm{O}_{2}, \mathrm{SO}_{2}$, particulate, and flow. The measurements from the analyzers will be used for performance monitoring of the unit and to determine compliance with federal and state air quality regulations including the EPA's Code of Federal Regulations, Part 40.

\subsubsection{Major Components}

The Combustion Gases Sampling and Analysis System will include all components of the Continuous Emissions Monitoring System (CEMS).

\subsubsection{System Description}

The CEMS will include analyzer equipment to measure stack emissions plus a Data Acquisition System (DAS). Signals from the analyzers and instrumentation will be continuously monitored by the computer-based data acquisition computer. The DAS will process the measurement data and generate emissions data reports as required by federal and state air quality regulations. Emissions data will be continuously transmitted to the DCIS for operator viewing in the Main Control Room. Alarms will be initiated when the emission levels exceed preselected limits. The gas analyzers will be either the full extractive or dilution extractive type.

\subsubsection{System Design Requirements}

The design of the combustion gas monitors will be in accordance with the requirements of the CEMS provisions established in the environment licensing permits.

\subsection{Calculation of Plant Emissions and Performance}

Full load performance for the gas turbines under evaluation for use in the project, has been performed. Table 1 provides preliminary results of the predicted plant performance analysis. Repowering with the PCFB is anticipated to 


\begin{tabular}{|c|c|c|}
\hline \multicolumn{3}{|c|}{$\begin{array}{c}\text { Table } 1 \\
\text { Predicted DMEC-1 Plant Performance }\end{array}$} \\
\hline & $\begin{array}{l}\text { Western Coal } \\
\text { Flow Rate } \\
(\mathrm{lb} / \mathrm{h})\end{array}$ & $\begin{array}{l}\text { Illinois Coal } \\
\text { Flow Rate } \\
(\mathrm{lb} / \mathrm{h})\end{array}$ \\
\hline \multicolumn{3}{|l|}{ Material and Gas Flows } \\
\hline \multicolumn{3}{|l|}{ Flow Rate, $\mathrm{lb} / \mathrm{h}$} \\
\hline Coal Paste & 132,300 & 88,600 \\
\hline Limestone & 1,900 & 10,600 \\
\hline Combustion Air & 824,400 & 824,400 \\
\hline Stack Exhaust Gas & 959,900 & 903,500 \\
\hline Ash and Spent Sorbent & 7,700 & 20,100 \\
\hline \multicolumn{3}{|l|}{ Regulated Emissions } \\
\hline $\begin{array}{l}\mathrm{SO}_{2} \text { Reduction for All Fuels, } \\
\text { percent }\end{array}$ & 90 & 90 \\
\hline $\mathrm{NO}_{x}, \mathrm{lb} / \mathrm{MMBtu}$ & 0.3 & 0.3 \\
\hline Particulate, lb/MMBtu & 0.03 & 0.03 \\
\hline \multicolumn{3}{|l|}{ Power Output (Gross) } \\
\hline Gas Turbine, MW & 20.4 & 16.6 \\
\hline Steam Turbine, MW & 66.5 & 63 \\
\hline $\begin{array}{l}\text { Approximate Improvement in Net } \\
\text { Plant Heat Rate After Repowering } \\
\text { with the PCFB, percent }\end{array}$ & 15 & $\mathrm{~N} / \mathrm{A}$ \\
\hline
\end{tabular}


improve the heat rate of the plant by about 15 percent while reducing plant emissions to compliance with New Source Performance Standards.

As is the case for any repowering of an aged low-pressure nonreheat steam turbine, the heat rate of the DMEC-1 unit will be limited by the efficiency of the existing steam turbine and plant station service requirements. With a new conventional reheat steam turbine, net plant efficiencies of over 42 percent $(8,100 \mathrm{Btu} / \mathrm{kWh}$ net) are achievable with the PCFB cycle planned for demonstration in the DMEC-1 project. Efficiencies as high as 45 to 46 percent (7,400 to 7,600 Btu/kWh net) are achievable with the advanced PCFB cycle where higher gas turbine inlet temperatures are utilized.

A key part of the project has been, and will continue to be, the design verification activities accomplished through continued operation of Ahlstrom Pyropower's 10 MW PCFB pilot plant at Karhula, Finland. Two of the three design coals for the project, Illinois No. 6 and Western subbituminous coal (Powder River Basin), have been run in the pilot plant to provide confirmation of such key design variables such as emission performance, calcium/sulfur molar ratio, combustion efficiency, excess air requirements, optimum paste moisture content, heat transfer coefficient, etc. Selected performance results from the pilot plant are reported below.

\subsubsection{Carbon Conversion Efficiency}

Figure 19 shows a plot of carbon conversion efficiency versus load for Illinois No. 6 (high sulfur bituminous coal) and low sulfur subbituminous coal (Newlands and Rawhide). The data indicates conversion efficiencies between 99.8 and 100 percent from approximately 40 to 100 percent load. Combustion temperature ranged from $1,500^{\circ} \mathrm{F}$ to $1,600^{\circ} \mathrm{F}$ with excess air levels of 4 to 30 percent. This excellent performance is attributable to the high partial pressure of oxygen inside the combustion chamber which leads to accelerated and improved combustion of the coal particles under pressurized conditions. The results compare favorably with coal gasification and contribute to the high cycle efficiency of the PCFB.

\subsection{2 $\mathrm{SO}_{2}$ Removal}

Figure 20 shows a graph of $\mathrm{SO}_{2}$ removal efficiency versus $\mathrm{Ca} / \mathrm{S}$ molar ratio for both the high sulfur and low sulfur coals. In order to achieve 90 percent removal, a Ca/S molar ratio of approximately 1.1 is required for the high sulfur coal while the 


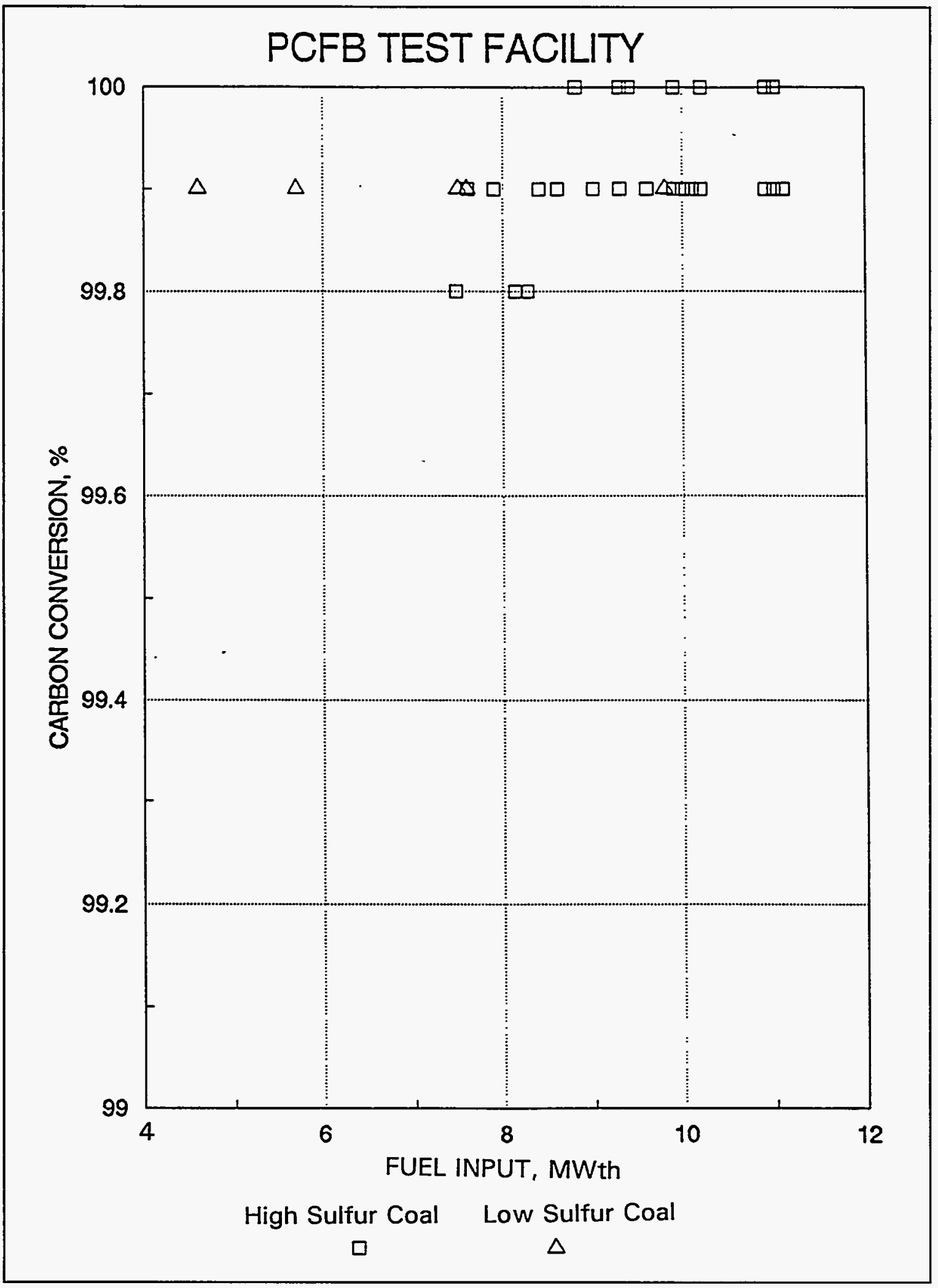

Figure 19: Combustion Efficiency 


\section{PCFB TEST FACILITY}

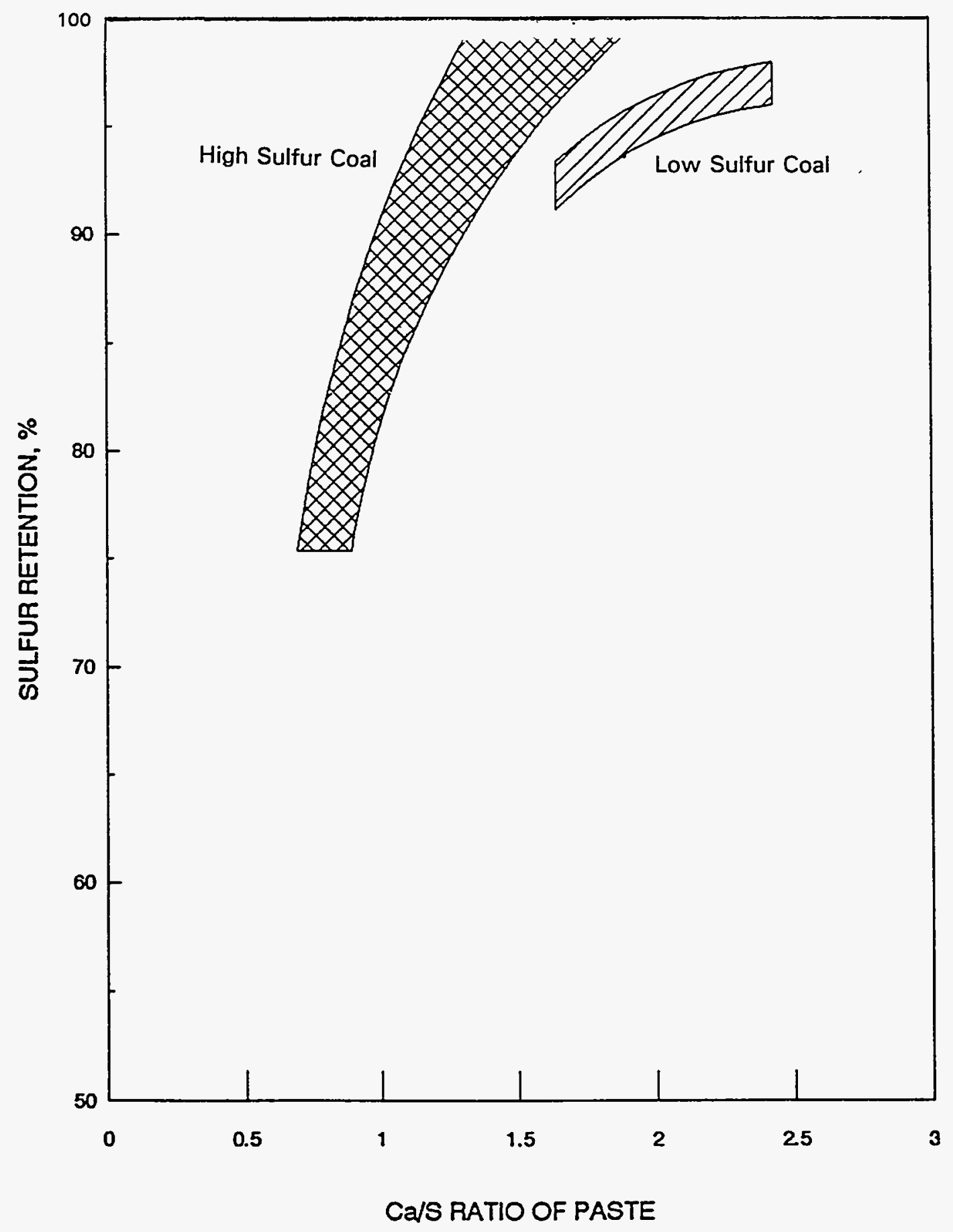

Figure 20: $\mathrm{SO}_{2}$ Removal Versus $\mathrm{Ca} / \mathrm{S}$ Molar Ratio 
low sulfur coal requires a $\mathrm{Ca} / \mathrm{S}$ molar ratio of about 1.4. At slightly higher calcium sulfur ratios, 98 to 99 percent removal was demonstrated. The calcium considered in these ratios is that of the limestone. No fuel bound calcium is included.

\subsection{3 $\mathrm{NO}_{x}$ Emissions}

Figure 21 presents $\mathrm{NO}_{\mathrm{x}}$ emissions as a function of load for the low sulfur coal indicating that the resulting emissions are well below current federal standards. Ahlstrom Pyropower has also successfully used ammonia injection to provide noncatalytic reduction of $\mathrm{NO}_{\mathrm{x}}$ emissions in atmospheric circulating fluidized bed ACFB

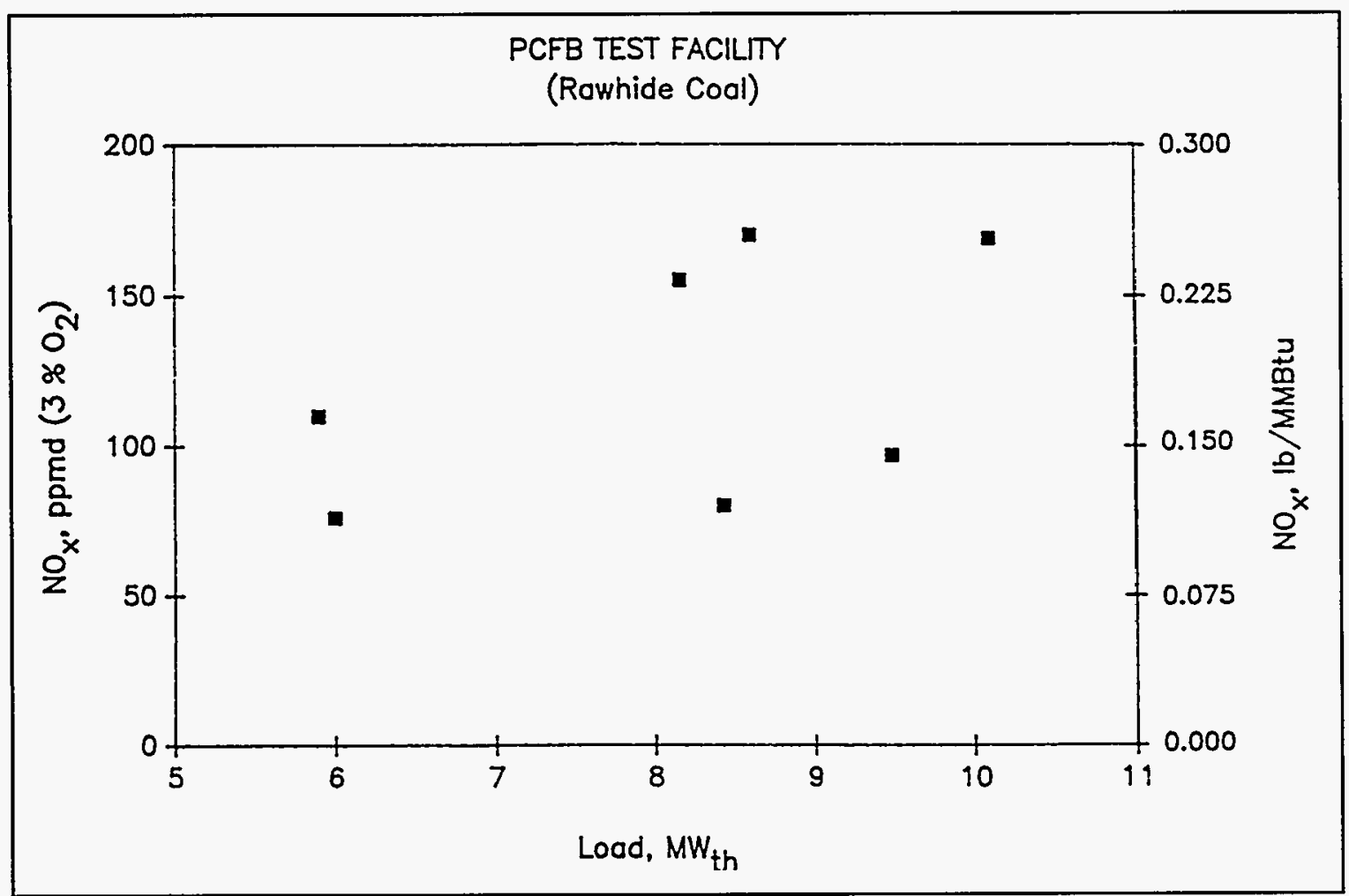

Figure 21: $\mathrm{NO}_{\mathrm{x}}$ Emission Versus Load

boilers where very low $\mathrm{NO}_{\mathrm{x}}$ emissions are required (approximately $0.1 \mathrm{lb} / \mathrm{MMBtu}$ or lower). This same technique has also been shown to be very effective for pressurized conditions and emissions as low as $0.04 \mathrm{lb} / \mathrm{MMBtu}$ have been demonstrated in the PCFB pilot plant.

\subsubsection{Carbon Monoxide (CO) Emissions}

Figure 22 shows $\mathrm{CO}$ emissions as a function of load. The data points measured before the filter indicate the effect of gas residence time. While the test data are 


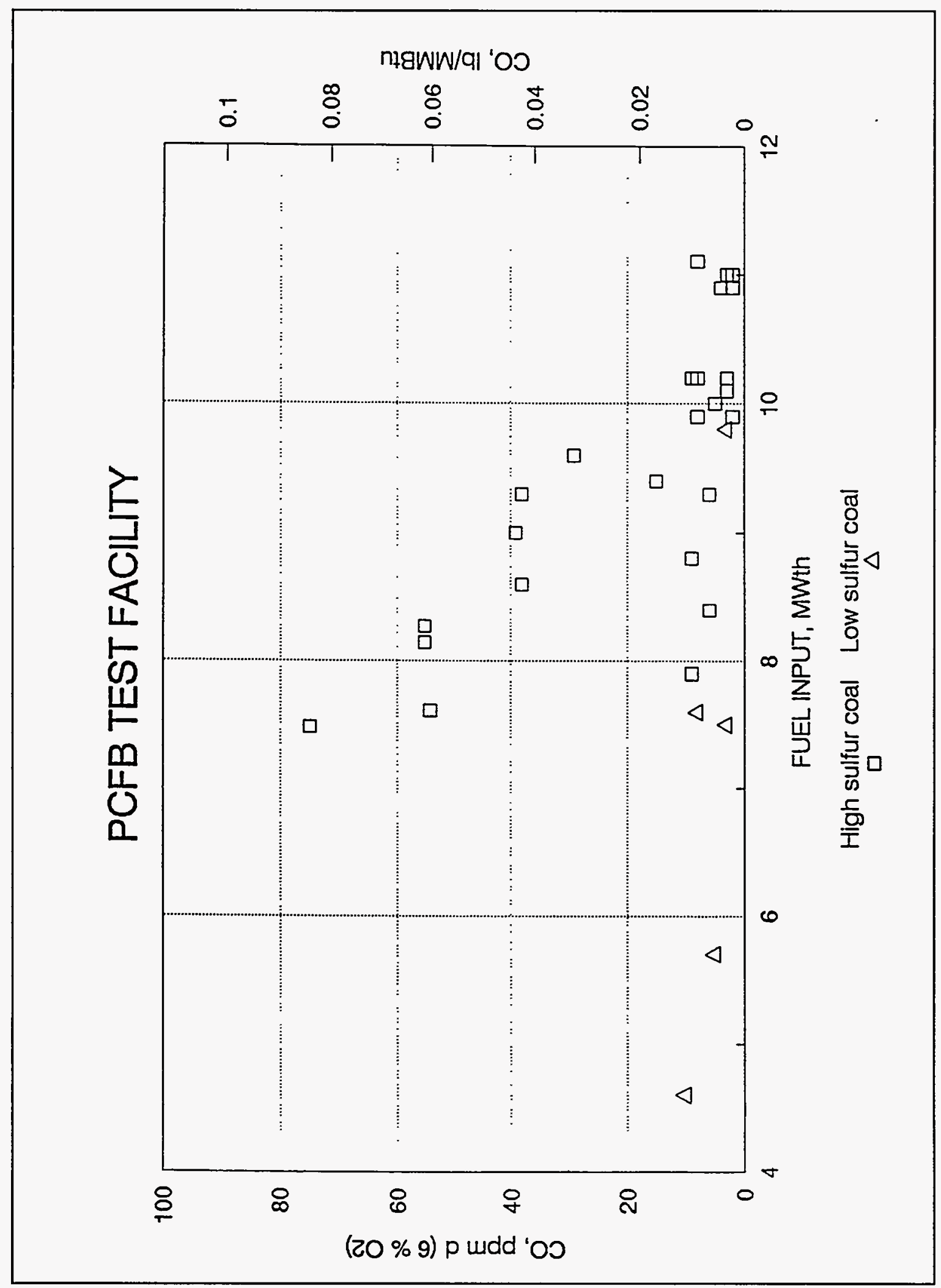

Figure 22: CO Emission Versus Load 
excellent, even better results would be expected in a commercial size plant due to the greater gas residence time that would occur.

\subsection{5 $\mathrm{N}_{2} \mathrm{O}$ Emissions}

$\mathrm{N}_{2} \mathrm{O}$ emissions have also been measured in the pilot plant. While $\mathrm{N}_{2} \mathrm{O}$ emissions are not currently being regulated by the Environmental Protection Agency or state and county pollution control agencies, there is considerable test work being performed on operating units to determine what levels are being generated with various combustion technologies. Measurements to date in the pilot plant indicate $\mathrm{N}_{2} \mathrm{O}$ levels of less than $0.03 \mathrm{lb} / \mathrm{MMBtu}$ being formed in a PCFB boiler at combustor temperatures of $1,540^{\circ} \mathrm{F}$ to $1,600^{\circ} \mathrm{F}$. 